medRxiv preprint doi: https://doi.org/10.1101/2021.10.24.21265240; this version posted October 26, 2021. The copyright holder for this preprint (which was not certified by peer review) is the author/funder, who has granted medRxiv a license to display the preprint in It is made available under a CC-BY-NC-ND 4.0 International license.

\title{
Distinct effects of single plant-based vs. animal-based meals on satiety and mood revealed by real-world smartphone-embedded studies
}

Evelyn Medawar ${ }^{1,2,3}$, Marie Zedler ${ }^{1}$, Larissa de Biasi ${ }^{1}$, Arno Villringer ${ }^{1,2,3,4}$, A. Veronica Witte ${ }^{1,4}$

${ }^{1}$ Department of Neurology, Max Planck Institute for Human Cognitive and Brain Sciences, Leipzig, Germany

${ }^{2}$ Berlin School of Mind and Brain, Humboldt-Universität zu Berlin, Germany

${ }^{3}$ Charité - Universitätsmedizin Berlin; Humboldt-Universität zu Berlin, Germany

${ }^{4}$ Clinic for Cognitive Neurology, University of Leipzig Medical Center, Leipzig, Germany

Corresponding author: Evelyn Medawar, Department of Neurology, Max Planck Institute for Human Cognitive and Brain Sciences, Stephanstr. 1A, 04103 Leipzig, Germany, medawar@cbs.mpg.de

Keywords: plant-based, animal-based, single-meal, hunger, satiety, mood, planetary health diet, smartphone-based, online study 
medRxiv preprint doi: https://doi.org/10.1101/2021.10.24.21265240; this version posted October 26, 2021. The copyright holder for this preprint (which was not certified by peer review) is the author/funder, who has granted medRxiv a license to display the preprint in

It is made available under a CC-BY-NC-ND 4.0 International license .

\section{Abstract (250 words)}

Adopting plant-based diets high in fiber may reduce global warming and obesity prevalence. Physiological and psychological determinants of plant-based food decision-making remain unclear, particularly in real-life settings. As fiber has been linked with improved gut-brain signaling, we hypothesized that a single plant-based compared to an animal-based meal, would induce higher satiety, higher mood and less stress.

In three smartphone-based studies adults ( $\left.\mathrm{n}_{\text {all }}=16,379\right)$ ranked satiety and mood on 5/10-point Likert scales before and after meal intake. Statistical analyses comprised linear mixed models, extended by nutrient composition, taste ratings, gender, social interaction, type of decision and dietary adherence to consider potential confounding.

Overall, meal intake induced satiety and higher mood. Against our hypotheses, plant-based meal choice did not explain differences in hunger after the meal. Considering mood, individuals choosing a plant-based meal reported slightly higher mood before the meal and smaller mood increases after the meal compared to those choosing animal-based meals (post-meal* plantbased: $b=-0.06, t=-3.6$, model comparison $p<.001$ ). Protein content marginally mediated postmeal satiety, while gender and taste ratings had a strong effect on satiety and mood in general.

In this series of large-scale online studies, we could not detect profound effects of plant-based vs. animal-based meals on satiety and mood. Instead of meal category, satiety and mood depended on taste and protein content of the meal, as well as dietary habits and gender. Our findings might help to develop strategies to increase acceptability of healthy and sustainable plant-based food choices.

\section{Significance Statement (120 words)}

Despite increasing awareness of plant-based diets as lifestyle- and climate-friendly option, the effects of plant-based meals on physiology and psychology remain largely understudied. Realworld large-scale studies looking at differential effects of plant-based vs. animal-based meals are missing. Yet, investigating the effects of meal category will help to understand underlying decision-making strategies and inform governmental policies and individual meal choices. In three large-scale online studies set in a real-world environment with over 16,000 datapoints, we showed that meal category had minor impact only on post-meal satiety and mood ratings compared to timepoint and demographic factors. We propose that our findings should be considered when designing cafeteria menus, by increasing taste and protein content, in particular of plant-based meals, in (university) cafeterias. 
medRxiv preprint doi: https://doi.org/10.1101/2021.10.24.21265240; this version posted October 26, 2021. The copyright holder for this preprint (which was not certified by peer review) is the author/funder, who has granted medRxiv a license to display the preprint in

It is made available under a CC-BY-NC-ND 4.0 International license.

\section{Introduction}

Plant-based diets, high in fiber (i.e., non-digestible carbohydrates) stemming from grain products, bread, potatoes, vegetables, legumes and fruits, are linked with planetary [1, 2] and human health $[3,4]$. An extensive meta-analysis showed that higher intake of food items rich in dietary fiber mediates the benefits of healthy lifestyles on non-communicable diseases such as obesity in a dose-response relationship [5]. Consequently, increasing daily fiber intake from today's $\sim 15 \mathrm{~g}$ to $50 \mathrm{~g}$ on a global scale, but in particular in Westernized diets, has been proposed to lead to overall extended lifespan and reduced health-care costs [6]. Eventually, adopting more plant-based diets on a global scale could thus in the long run help to counter ever-increasing rates of obesity and greenhouse gas emissions likewise. Knowledge on the physiological and psychological factors, including hunger, mood, food availability and culture, that link with plant-based food decisionmaking remain however surprisingly largely understudied.

On the one hand, several „bottom-up“ physiological mechanisms, prompted by ingested nutrients and processed in the brain, have been proposed to mediate acute metabolic effects signaling post-prandial satiety, reward and contentment, but also long-term metabolic (dys-)regulation and (de-)sensitization [7]. Macronutrient content most likely modulates appetite control, as energy density or protein content of a single meal determines subsequent metabolic activity $[8,9]$ and in turn influences future meal intake via gut-brain hormonal signaling [10]. Indeed, repetitive cueing with highly palatable foods led to habituation of reward-associated dopaminergic signaling [11]. In contrast to high caloric foods, dietary fiber not only moderately improved body weight status independent of energy intake across 62 trials [12], but also activates appetite-regulatory pathways via anorectic hormones, thereby ameliorating high-caloric food craving and other psychobiological processes [13]. While the timeframe of those putative effects remain unclear [14], fiber and polyunsaturated fats may contribute to healthy feeding-related signaling and neuronal survival, for example by improving glucose and insulin metabolism, by balancing energy homeostasis through protecting hypothalamic neurons from inflammation [15] or by contributing to a healthy energy-harvesting profile of the gut microbiome [16].

On the other hand, „top-down“ psychological mechanisms include for instance (un-)successful self-control and cognitive strategies towards health or moral goals help to make choices aligned with inner beliefs and self-reinforce dietary habits. Those choices are planned not impulsive, and in the case of food decision-making may often - but not always (e.g. in the case of eating disorders) - lead to healthier food choices [17]. In the case of vegetarians and vegans, restrictive eating has been linked with higher risk for depressive symptoms (meta-analysis of $n \sim 50 \mathrm{k}$ participants [18]). Determinants and timeframe and also the reasons for the potential link between restrictive diets and depressive mood remain unclear and might include social exclusion, isolation or stigma in the long term. Conversely, healthy and adequate nutrient intake, including high fiber intake, has been associated with lower depressive symptoms and anxiety in observational (metaanalysis, [19]) and interventional studies ([20]), potentially via microbiota-driven modification of gene expression and anti-inflammatory properties [21]. Overall, reverse causation for food-mood relationships remains an unsolved issue [22] and whether single meals different in fiber content affect mood remains unclear.

Targeting food choice environment such as labeling, reducing portion size, imposing taxes and modifying availability are common tools to modulate food decision-making [23]. For instance, a recent study in university cafeterias doubled the availability of vegetarian meals, which led to an increase of $41-79 \%$ sales of plant-based meals across over $90 \mathrm{k}$ meals, without a drop in overall sales [24]. Sales and attractiveness increased when product packaging included labels that prompt sensory or contextual experiences, which was found to be less frequent for plant-based 
medRxiv preprint doi: https://doi.org/10.1101/2021.10.24.21265240; this version posted October $26,2021$. The copyright holder for this
preprint (which was not certified by peer review) is the author/funder, who has granted medRxiv a license to display the preprint in

It is made available under a CC-BY-NC-ND 4.0 International license .

products [25]. Yet, besides shaping food choice internally and externally, perceived physiological and psychological effects of such decisions and meal intakes remain unknown.

In sum, plant-based diets high in fiber resemble the current diet of choice for climate reasons, and some, but not all, interventional studies and meta-analyses raise the hypothesis that plantbased diets contribute to better maintenance of gut-brain signaling including satiety regulation and food reward sensitivity through nutrient-related improvements in metabolic factors. Only few studies however report significant effects of a single plant-based meal on post-prandial satiety and mood, and which factors modify this relation. To address these questions, we aimed to determine satiety and mood before and after a single plant-based (vegetarian, vegan) meal or, as a comparison, animal-based (fish, meat) meal served in university cafeterias providing a broad selection of different meals in the same environment in a demographically homogeneous population. To this end, we designed a series of novel smartphone-based studies: firstly, a largescale study with free meal choice covering most of German university cafeterias, secondly, a study focusing on a smaller, deeply phenotyped sample of omnivorous individuals with free meal choice, and thirdly, a follow-up study of the latter with random allocation of meals.

We hypothesized that a plant-based meal will lead to higher satiety, better mood and less stress compared to an animal-based meal based on larger fiber content and pre-registered our analysis plan at the open science framework (osf.io). In addition, we explored whether a voluntary decision to eat a plant-based meal (vegetarian or vegan) compared to an animal-based meal will be more frequently made upon planned (vs. impulsive) decisions, and if higher fiber content in the meals will mediate higher mood and satiety and lower stress, whereas higher unrefined sugar and fat content will mediate the opposite. The former potential effects will be masked in participants that followed, and in particular in those that also disliked, a non-voluntary decision of meal category. Additionally, we explored other demographic factors that might influence food choice, such as gender, socioeconomic status, sleep and habitual eating habits.

\section{Results}

\section{Sample size, dietary habits and gender distribution}

In total 16,135 observations were included in the analysis after data curation for the app study (predominant dietary habits according to self-report: omnivorous, $n=11,600$, vegetarian, $n=$ 3,456 , vegan, $n=911$ ), as well as 173 in sub-study two and 71 in sub-study three (all omnivorous). Reported meals were $47-61 \%$ animal-based across studies. Two of the most frequent meals were pasta and currywurst, for study design and exemplary cafeteria meals, see Figure 1. Sample size dropped for exploratory data analysis due to missing data (SI Figure 1). 


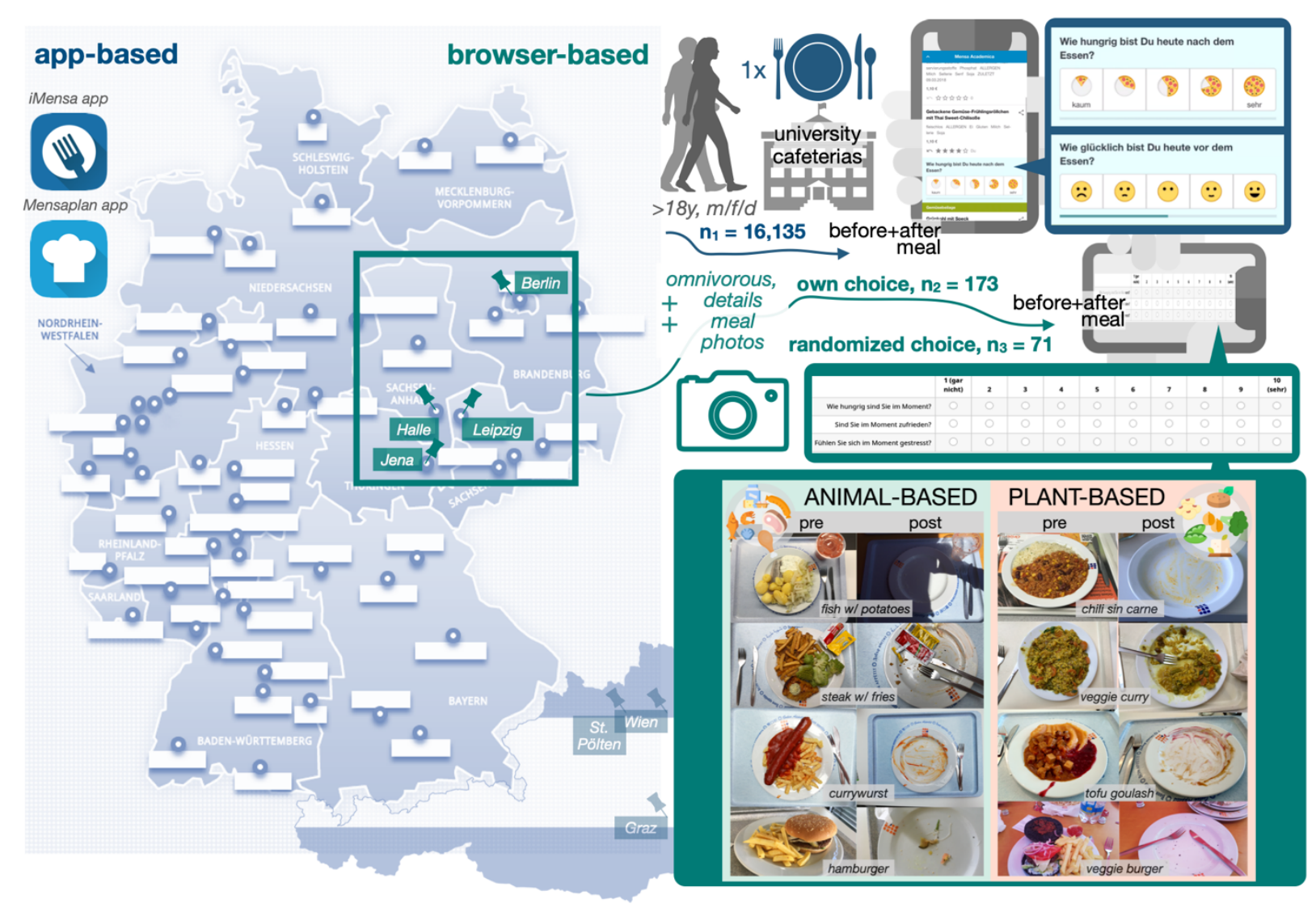

Figure 1: Study design: Adults $(m, f, d)$ consuming a single meal in university cafeterias rated hunger and mood using Likert scales before and after that meal with smartphones or mobile devices, in an app study $\left(n_{1}=16,135,5\right.$-point scales, in dark blue) or in a more detailed web-based survey (omnivorous diet habits only, 10-point scales, $n_{2}=173$ : free choice, $n_{3}=71$ : randomized choice; in petrol). Photos show exemplary pre- and post-meal plates for both meal categories (in petrol). Screenshots taken from iMensa app directly and meal photos provided by study participants (available at https://osf.io/mqc5d/). Germany map adapted from https://www.studentenwerke.de/de/landkarte.

For details about demographic and other parameters see Figure 2 and Table 1. Briefly, in the app study omnivorous dieters chose an animal-based meal more frequently $(69 \%)$ and vegetarians and vegans mostly chose plant-based meals $(84 \%)\left(X^{2}(2)=3679.3, p<2.2 \times 10^{-16}\right)$. Note, that a substantial proportion of those reporting to eat predominantly vegan/vegetarian chose an animal-based meal (16\%). On average, women were more likely to choose a plant-based meal (app study: $\mathrm{X}^{2}=731.4, \mathrm{p}<10^{-10}$, female $=58 \%$, diverse $=45.3 \%$, male $=37.3 \%$; sub-study 2 : female $=65 \%$, diverse $=2 \%$, male $=33 \%$; sub-study 3 : allocation was randomized). Both female and diverse gender reported more than twice as often predominantly vegan/vegetarian dietary habits compared to male in the app study $\left(X^{2}=1266, p<10^{-10}\right.$, female $=40.4 \%$, diverse $=54.8 \%$, male $=16.5 \%)$. In sub-study 2 , neither body mass index (BMI), income or general well-being differed across meal categories ( $p_{\text {all }}>0.26$ ). Omnivorous dieters choosing a plant-based meal were characterized by significantly higher habitual fiber intake ( $22 \pm 11 \mathrm{vs.} 18 \pm 9 \mathrm{~g}$ fiber / day, $\mathrm{p}$ $<0.05)$ and marginally higher scores for cognitive restraint and hunger in the TFEQ subscales $(p$ $<0.05$ ) compared to those choosing animal-based meals (Table 1). No differences in personality traits or general well-being were found. Respective differences were not significant for the randomized allocation samples in sub-study 3 . 
medRxiv preprint doi: https://doi.org/10.1101/2021.10.24.21265240; this version posted October 26, 2021. The copyright holder for this preprint (which was not certified by peer review) is the author/funder, who has granted medRxiv a license to display the preprint in It is made available under a CC-BY-NC-ND 4.0 International license.

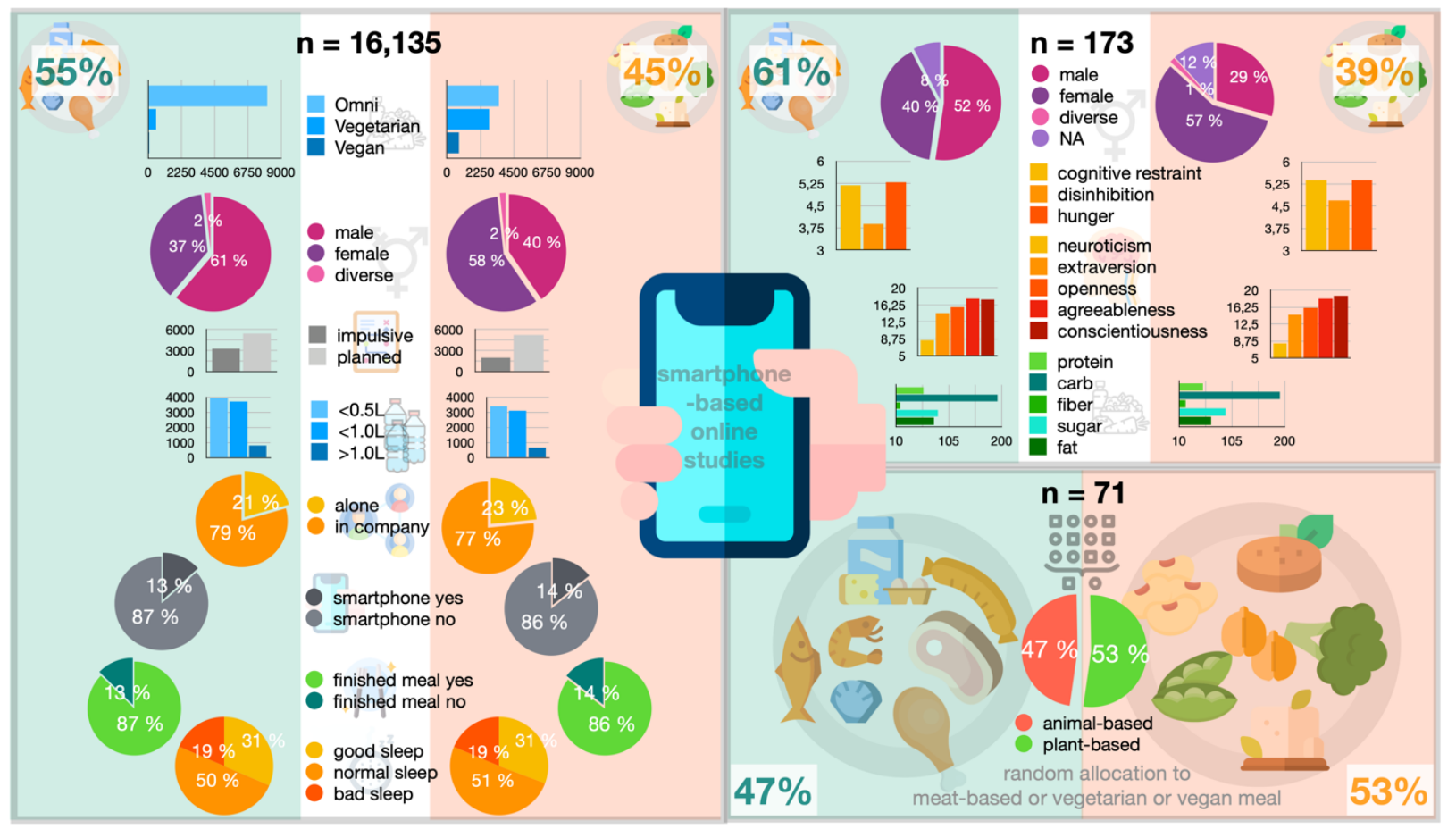

Figure 2: Demographic factors and study sample descriptives of sub-studies 1, 2 and 3. Image rights: Freepik (smartphone, diet, water, network, eat, clock, broccoli, tofu, peas, chickpea, soy, vegan, sausage, chop, food), Smashicons (brain), DinosoftLabs (chicken leg), surgan (seafood). 
medRxiv preprint doi: https://doi.org/10.1101/2021.10.24.21265240; this version posted October 26, 2021. The copyright holder for this preprint (which was not certified by peer review) is the author/funder, who has granted medRxiv a license to display the preprint in perpetuity.

It is made available under a CC-BY-NC-ND 4.0 International license .

Table 1: Demographic information across studies according to meal choice. Significant differences according to Chi-tests or Wilcoxon tests between meal categories are marked in bold.

\begin{tabular}{|c|c|c|c|}
\hline \multirow[t]{2}{*}{ Variable } & \multicolumn{3}{|c|}{$\begin{array}{l}\text { app-based } \\
n=16,135\end{array}$} \\
\hline & animal-based meal & plant-based meal & $\begin{array}{l}\text { Chi-test / Wilcoxon test between } \\
\text { meal categories }\end{array}$ \\
\hline Dietary adherence & $\begin{array}{l}\text { Omnivorous: } 8053 \\
\text { Vegetarian: } 576 \\
\text { Vegan: } 116\end{array}$ & $\begin{array}{l}\text { Omnivorous: } 3546 \\
\text { Vegetarian: } 2879 \\
\text { Vegan: } 794\end{array}$ & $X^{2}(2)=3679.3, p<2.2 \times 10^{-16}$ \\
\hline Gender & $\begin{array}{l}3233 \mathrm{~F} \\
5368 \mathrm{M} \\
155 \mathrm{D}\end{array}$ & $\begin{array}{l}4185 \mathrm{~F} \\
2923 \mathrm{M} \\
124 \mathrm{D}\end{array}$ & $X^{2}(2)=731.4, p<2.2 \times 10^{-10}$ \\
\hline $\begin{array}{l}\text { Impulsive vs. planned } \\
\text { decision }\end{array}$ & $\begin{array}{l}\text { impulsive: } 3279 \\
\text { planned: } 5457\end{array}$ & $\begin{array}{l}\text { impulsive: } 1997 \\
\text { planned: } 5222\end{array}$ & $X^{2}(1)=173.6, p<2.2 \times 10^{-16}$ \\
\hline Drinking volume last $\mathbf{2 h}$ & $\begin{array}{l}<0.5 \mathrm{~L}: 4175 \\
<1.0 \mathrm{~L}: 3706 \\
\text { >1.0L: } 807\end{array}$ & $\begin{array}{l}<0.5 \mathrm{~L}: 3403 \\
<1.0 \mathrm{~L}: 3131 \\
>1.0 \mathrm{~L}: 646\end{array}$ & $X^{2}(2)=1.6, p=0.46$ \\
\hline Social interaction during meal & $\begin{array}{l}\text { alone: } 1783 \\
\text { in company: } 6876\end{array}$ & $\begin{array}{l}\text { alone: } 1675 \\
\text { in company: } 5484\end{array}$ & $X^{2}(1)=17.9, p<2.310^{-5}$ \\
\hline Smartphone use during meal & $\begin{array}{l}\text { yes: } 1156 \\
\text { no: } 7481\end{array}$ & $\begin{array}{l}\text { yes: } 1019 \\
\text { no: } 6121\end{array}$ & $X^{2}(1)=2.5, p=0.11$ \\
\hline Finished meal & $\begin{array}{l}\text { yes: } 7746 \\
\text { no: } 1123\end{array}$ & $\begin{array}{l}\text { yes: } 6081 \\
\text { no: } 1025\end{array}$ & $X^{2}(1)=5.9, p=0.0153$ \\
\hline Sleep last night & $\begin{array}{l}\text { good: } 2674 \\
\text { normal: } 4245 \\
\text { bad: } 1576\end{array}$ & $\begin{array}{l}\text { good: } 2157 \\
\text { normal: } 3555 \\
\text { bad: } 1308\end{array}$ & $X^{2}(2)=1.1, p=0.59$ \\
\hline
\end{tabular}

Abbreviations: N.A.: no answer; F: female; D: diverse; M: male 


\begin{tabular}{|c|c|c|c|c|c|c|}
\hline \multirow[t]{2}{*}{ Variable } & \multicolumn{3}{|c|}{$\begin{array}{l}\text { study } 2 \text { (free choice) } \\
\text { n=173 (FFQ: } n=108, \text { NEOFFI: } n=98 \text {, TFEQ: } n=91 \text { ) }\end{array}$} & \multicolumn{3}{|c|}{$\begin{array}{l}\text { study } 3 \text { (randomized choice) } \\
n=71 \text { (FFQ: } n=52 \text {, NEOFFI: } n=49 \text {, TFEQ: } n=43 \text { ) }\end{array}$} \\
\hline & $\begin{array}{l}\text { animal-based } \\
\text { meal }\end{array}$ & plant-based meal & $\begin{array}{l}\text { Chi-test / Wilcoxon test } \\
\text { between meal categories }\end{array}$ & animal-based meal & plant-based meal & $\begin{array}{l}\text { Chi-test / Wilcoxon test } \\
\text { between meal categories }\end{array}$ \\
\hline Dietary adherence & $\begin{array}{l}\text { Omnivorous: } 173 \\
\text { Vegetarian: } 0 \\
\text { Vegan: } 0\end{array}$ & $\begin{array}{l}\text { Omnivorous: } 173 \\
\text { Vegetarian: } 0 \\
\text { Vegan: } 0\end{array}$ & - & $\begin{array}{l}\text { Omnivorous: } n=71 \\
\text { Vegetarian: } n=0 \\
\text { Vegan: } n=0\end{array}$ & $\begin{array}{l}\text { Omnivorous: } \mathrm{n}=71 \\
\text { Vegetarian: } \mathrm{n}=0 \\
\text { Vegan: } \mathrm{n}=0\end{array}$ & - \\
\hline Gender & $\begin{array}{l}42 \mathrm{~F} \\
55 \mathrm{M} \\
0 \mathrm{D} \\
8 \mathrm{~N} . \mathrm{A} .\end{array}$ & $\begin{array}{l}39 \mathrm{~F} \\
20 \mathrm{M} \\
1 \mathrm{D} \\
8 \mathrm{~N} . \mathrm{A} .\end{array}$ & $X^{2}(2)=9.2, p=0.01$ & $\begin{array}{l}19 \mathrm{~F} \\
12 \mathrm{M} \\
0 \mathrm{D} \\
5 \mathrm{~N} . \mathrm{A} .\end{array}$ & $\begin{array}{l}22 \mathrm{~F} \\
10 \mathrm{M} \\
0 \mathrm{D} \\
3 \mathrm{~N} . \mathrm{A} .\end{array}$ & $X^{2}(1)=0.13, p=0.72$ \\
\hline Income (categorical) & $\begin{array}{l}<500 €: 30 \\
500-1000 €: 33 \\
\text { 1000-1500€: } 16 \\
\text { 1500-2000€: } 4 \\
\text { 2000-2500€: } 4 \\
\text { N.A.: } 18\end{array}$ & $\begin{array}{l}<500 €: 17 \\
500-1000 €: 28 \\
\text { 1000-1500€: } 10 \\
\text { 1500-2000€: } 1 \\
\text { 2000-2500€: } 0 \\
\text { N.A.: } 12\end{array}$ & $X^{2}(4)=4.7, p=0.32$ & $\begin{array}{l}<500 €: 13 \\
\text { 500-1000€: } 12 \\
\text { 1000-1500€: } 4 \\
\text { 1500-2000€: } 0 \\
\text { 2000-2500€: } 0 \\
\text { NA: } 7\end{array}$ & $\begin{array}{l}\text { <500€: } 14 \\
\text { 500-1000€: } 14 \\
\text { 1000-1500€: } 1 \\
\text { 1500-2000€: } 0 \\
\text { 2000-2500€: } 0 \\
\text { NA: } 6\end{array}$ & $X^{2}(2)=2.0, p=0.37$ \\
\hline $\begin{array}{l}\text { Body-mass-index (BMI) } \\
\text { (self-reported) }\end{array}$ & $22.3 \pm 2.4 \mathrm{~kg} / \mathrm{m}^{2}$ & $22.2 \pm 2.6 \mathrm{~kg} / \mathrm{m}^{2}$ & $X^{2}(140)=143.6, p=0.40$ & $22.6 \pm 2.7$ & $23.1 \pm 4.6$ & $X^{2}(57)=58.3, p=0.42$ \\
\hline Finished meal & $\begin{array}{l}\text { yes: } 71 \\
\text { no: } 31 \\
\text { N.A.: } 3\end{array}$ & $\begin{array}{l}\text { yes: } 48 \\
\text { no: } 16 \\
\text { N.A.: } 4\end{array}$ & $X^{2}(1)=0.33, p=0.57$ & $\begin{array}{l}\text { yes: } 25 \\
\text { no: } 11\end{array}$ & $\begin{array}{l}\text { yes: } 22 \\
\text { no: } 13\end{array}$ & $X^{2}(1)=0.11, p=0.74$ \\
\hline $\begin{array}{l}\text { Drinking volume last } \mathbf{2 h} \\
\text { Water } \\
\text { Tea } \\
\text { Coffee }\end{array}$ & & & $\begin{array}{l}X^{2}(3)=0.9, p=0.82 \\
X^{2}(2)=1.8, p=0.41 \\
X^{2}(1)=1.3, p=0.25\end{array}$ & & & $\begin{array}{l}X^{2}(2)=2.7, p=0.26 \\
X^{2}(2)=0.1, p=0.93 \\
X^{2}(2)=4.9, p=0.09\end{array}$ \\
\hline Side dishes & $\begin{array}{l}\text { sides: } 25 \\
\text { desserts: } 10 \\
\text { other: } 6\end{array}$ & $\begin{array}{l}\text { sides: } 7 \\
\text { desserts: } 12 \\
\text { other: } 7\end{array}$ & & $\begin{array}{l}\text { sides: } 5 \\
\text { desserts: } 2 \\
\text { other: } 1\end{array}$ & $\begin{array}{l}\text { sides: } 6 \\
\text { desserts: } 4 \\
\text { other: } 3\end{array}$ & \\
\hline $\begin{array}{l}\text { General well-being } \\
\text { (WHO-5) }\end{array}$ & $14.3 \pm 4.5$ & $15.7 \pm 4.3$ & $X^{2}(21)=24.7, p=0.26$ & $15.1 \pm 4.2$ & $13.7 \pm 4.1$ & $X^{2}(16)=14.6, p=0.56$ \\
\hline $\begin{array}{l}\text { Eating traits }(n=108) \\
\text { Cognitive restraint } \\
\text { Disinhibition }\end{array}$ & $\begin{array}{l}5.2 \pm 4.2 \\
3.9 \pm 2.7\end{array}$ & $\begin{array}{l}5.4 \pm 3.7 \\
4.7 \pm 2.5\end{array}$ & $\begin{array}{l}X^{2}(14)=28.0, p=0.014 \\
X^{2}(11)=16.0, p=0.14\end{array}$ & $\begin{array}{l}5.5 \pm 4.1 \\
5.3 \pm 3.4\end{array}$ & $\begin{array}{l}5.5 \pm 4.1 \\
5.2 \pm 3.1\end{array}$ & $\begin{array}{l}X^{2}(14)=7.2, p=0.93 \\
X^{2}(12)=18.1, p=0.11\end{array}$ \\
\hline
\end{tabular}




\begin{tabular}{|c|c|c|c|c|c|c|}
\hline Hunger & $5.3 \pm 3.0$ & $5.4 \pm 2.8$ & $X^{2}(12)=22.1, p=0.037$ & $5.5 \pm 2.7$ & $5.7 \pm 3.5$ & $X^{2}(11)=4.5, p=0.95$ \\
\hline $\begin{array}{l}\text { Personality traits }(\mathbf{n}= \\
\text { 98) } \\
\text { Neuroticism } \\
\text { Extraversion } \\
\text { Openness } \\
\text { Agreeableness } \\
\text { Conscientiousness }\end{array}$ & $\begin{array}{l}8.4 \pm 4.7 \\
14.4 \pm 3.9 \\
15.8 \pm 5.3 \\
17.6 \pm 4.3 \\
17.5 \pm 4.1\end{array}$ & $\begin{array}{l}8.2 \pm 3.7 \\
14.6 \pm 3.5 \\
16.1 \pm 5.4 \\
18.2 \pm 3.8 \\
18.8 \pm 3.7\end{array}$ & $\begin{array}{l}X^{2}(18)=24.3, p=0.15 \\
X^{2}(17)=20.1, p=0.23 \\
X^{2}(20)=24.5, p=0.22 \\
X^{2}(17)=13.0, p=0.74 \\
X^{2}(15)=17.5, p=0.29\end{array}$ & $\begin{array}{l}9.2 \pm 5.2 \\
13.0 \pm 4.4 \\
13.2 \pm 5.4 \\
16.6 \pm 4.9 \\
18.3 \pm 4.1\end{array}$ & $\begin{array}{l}10.2 \pm 5.1 \\
13.2 \pm 3.2 \\
16.5 \pm 5.6 \\
17.4 \pm 5.4 \\
17.6 \pm 4.1\end{array}$ & $\begin{array}{l}X^{2}(17)=18.0, p=0.39 \\
X^{2}(16)=8.3, p=0.94 \\
X^{2}(20)=21.0, p=0.40 \\
X^{2}(18)=14.3, p=0.71 \\
X^{2}(15)=10.2, p=0.81\end{array}$ \\
\hline $\begin{array}{l}\text { Regular eating habits (n } \\
=91) \\
\text { Energy (kcal) } \\
\text { Protein }(\mathrm{g}) \\
\text { Carbohydrates }(\mathrm{g}) \\
\text { Fiber }(\mathrm{g}) \\
\text { Sugar }(\mathrm{g}) \\
\text { Fat }(\mathrm{g}) \\
\text { Coffee }(\mathrm{ml})\end{array}$ & $\begin{array}{l}1563 \pm 600 \\
60 \pm 27 \\
192 \pm 74 \\
18 \pm 9 \\
86 \pm 53 \\
79 \pm 53 \\
165 \pm 259\end{array}$ & $\begin{array}{l}1493 \pm 553 \\
54 \pm 26 \\
192 \pm 71 \\
22 \pm 11 \\
94 \pm 53 \\
68 \pm 39 \\
174 \pm 314\end{array}$ & $\begin{array}{l}W=1073, p=0.6746 \\
W=1164, p=0.2512 \\
W=1002, p=0.8887 \\
W=720, p=0.01663 \\
W=864, p=0.2137 \\
W=1139, p=0.3434 \\
X^{2}(14)=16.7, p=0.27\end{array}$ & $\begin{array}{l}1445 \pm 586 \\
58 \pm 30 \\
177 \pm 74 \\
16 \pm 8 \\
75 \pm 40 \\
60 \pm 33 \\
90 \pm 153\end{array}$ & $\begin{array}{l}1426 \pm 582 \\
54 \pm 28 \\
174 \pm 68 \\
18 \pm 11 \\
72 \pm 49 \\
80 \pm 57 \\
82 \pm 203\end{array}$ & $\begin{array}{l}W=237, p=0.8948 \\
W=255, p=0.5717 \\
W=232, p=0.9904 \\
W=223, p=0.8569 \\
W=259, p=0.5079 \\
W=228, p=0.9521 \\
X^{2}(8)=5.8, p=0.67\end{array}$ \\
\hline
\end{tabular}

Abbreviations: N.A.: no answer; F: female; D: diverse; M: male 
medRxiv preprint doi: https://doi.org/10.1101/2021.10.24.21265240; this version posted October 26, 2021. The copyright holder for this preprint (which was not certified by peer review) is the author/funder, who has granted medRxiv a license to display the preprint in perpetuity.

It is made available under a CC-BY-NC-ND 4.0 International license.

\section{Pre-registered main analysis \\ Effect of meal category on hunger, mood and stress}

In the app-study, in contrast to our hypothesis, there was no significant interaction effect of meal category and timepoint for hunger $(p=0.2$, Figure 3 A, Table 2). While individuals choosing a plant-based meal reported lower hunger on average (main effect, $\sim-1 / 10$ th points, $b=-0.10, t=$ - 6.8, model comparison $p<.001$ ) independent of meal category, average hunger dropped around 2 points on the 5-point Likert scale in both conditions (main effect, $b=-1.99, t=-179.4, p<0.001$ ). Considering mood, contrary to our hypothesis, post-meal mood increased $\sim 2 / 5$ th points less for individuals choosing a plant-based meal compared to an animal-based meal (interaction effect, post-meal ${ }^{*}$ plant-based: $b=-0.06, t=-3.6$, model comparison $p<.001$, Figure 3B). In parallel, mood was slightly higher in individuals eating a plant-based meal before the meal (animal-based: $3.48 \pm 1$ points vs. plant-based: $3.52 \pm 1$ points) and increased in all individuals after the meal (animal-based: +0.26 points, plant-based: +0.20 points). For sub-studies 2 and 3 no significant interaction effects on hunger or mood were observed. There was no significant main or interaction effects for stress. Average values and valence of betas of the effects of interest appeared similar to the app-study (for comparison of mean values see Figure 3C-D, Table 2). 
medRxiv preprint doi: https://doi.org/10.1101/2021.10.24.21265240; this version posted October 26, 2021. The copyright holder for this preprint (which was not certified by peer review) is the author/funder, who has granted medRxiv a license to display the preprint in perpetuity.

It is made available under a CC-BY-NC-ND 4.0 International license .

A

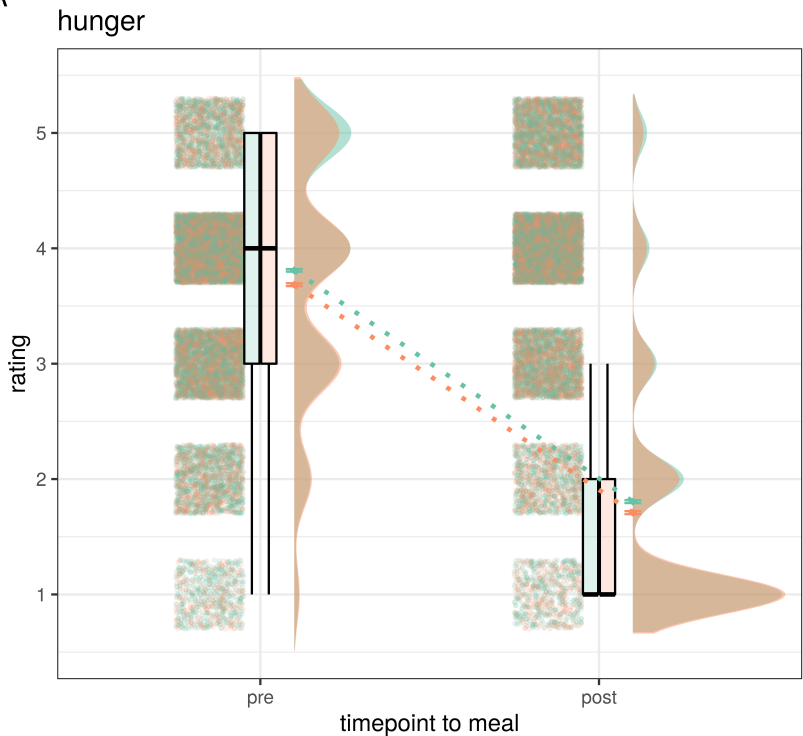

宁 plant-based

B

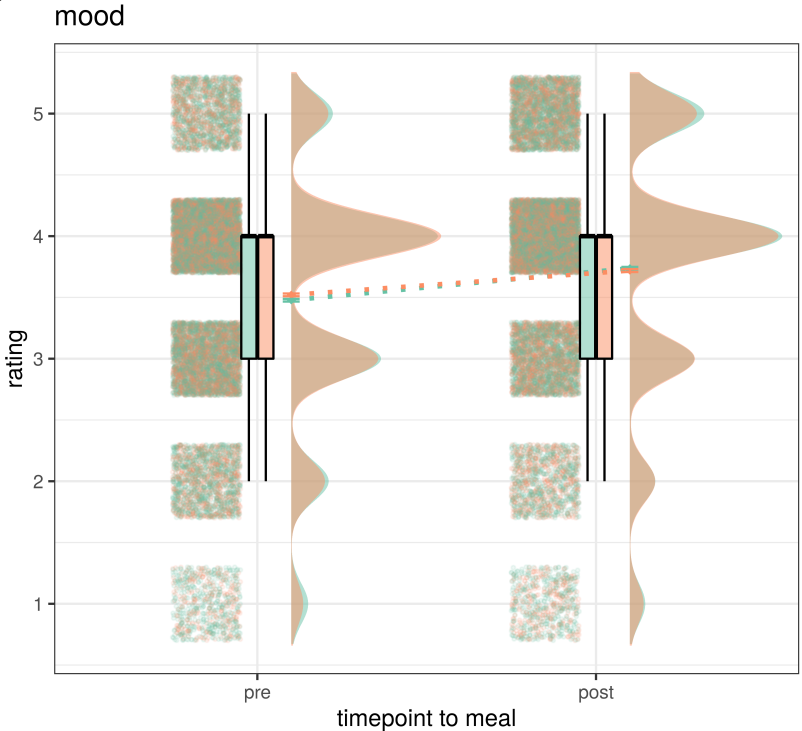

C
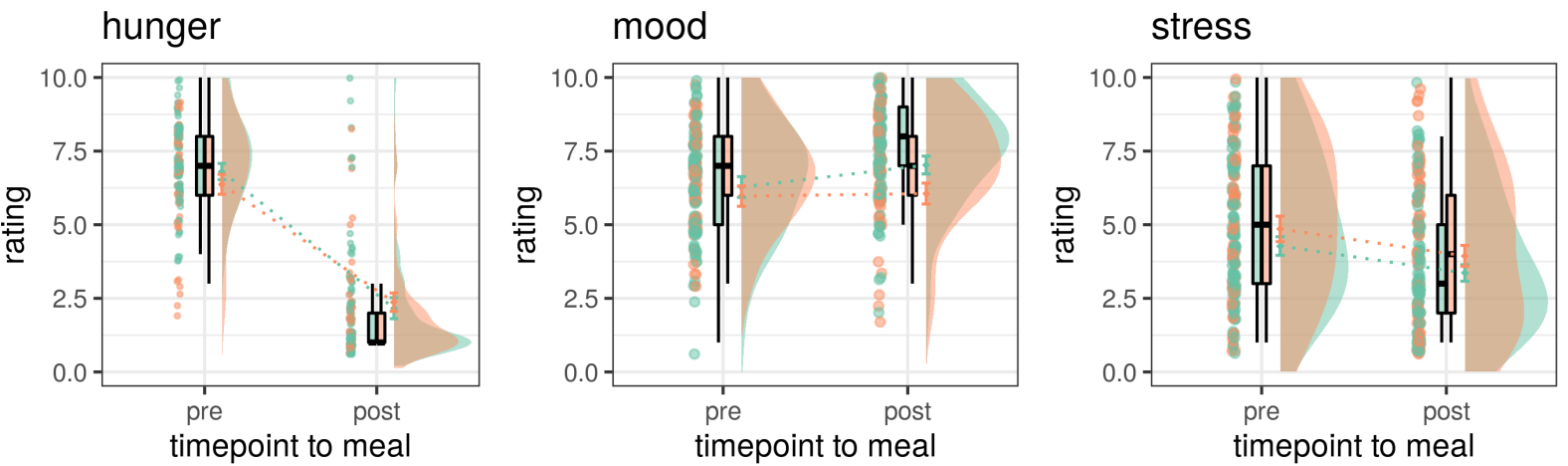

$\mathrm{D}$
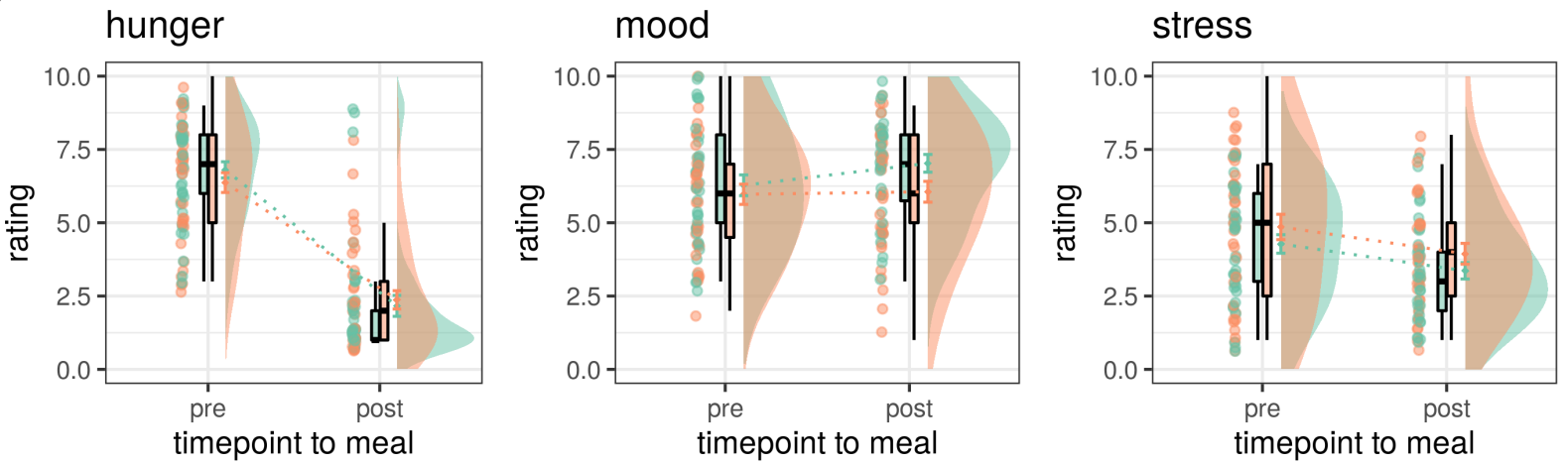

Figure 3: Mean ratings of pre- and post-meal meal category for hunger, mood/contentment and stress. App-study ratings ( $n=16135)$ depicted in A) hunger $B$ ) mood, C) sub-study 2 with free meal choice $(n=173)$ and $D)$ sub-study 3 with randomized meal allocation $(n=78)$. Median depicted as line, mean as dot, outliers (according to interquartile rule) as triangles. 
medRxiv preprint doi: https://doi.org/10.1101/2021.10.24.21265240; this version posted October 26, 2021. The copyright holder for this preprint (which was not certified by peer review) is the author/funder, who has granted medRxiv a license to display the preprint in It is made available under a CC-BY-NC-ND 4.0 International license

Table 2: Ratings for hunger, mood, stress across all studies. Mean \pm SD. Significant models of interest compared to null model in bold (LMM comparison $p<0.001)$.

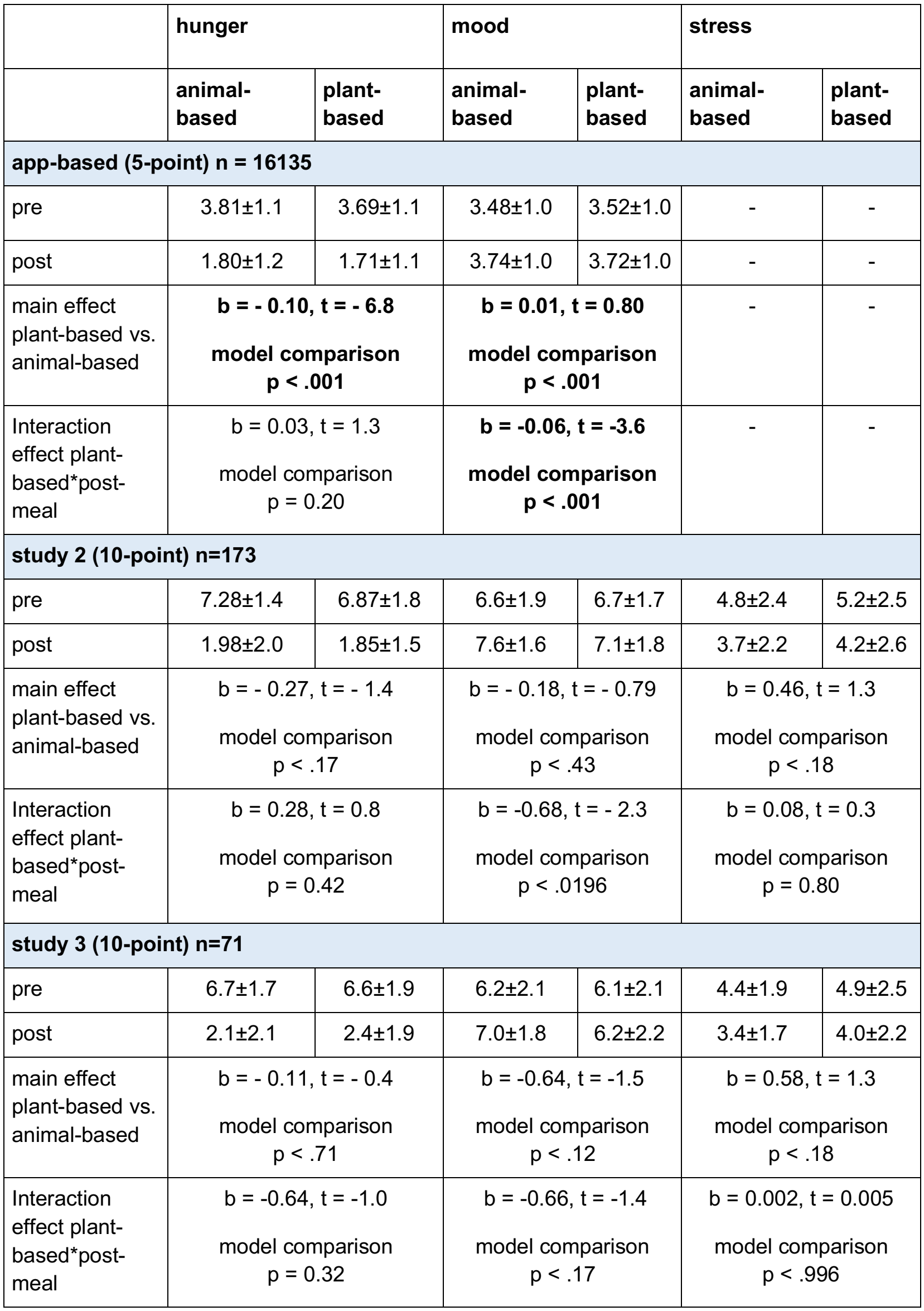

Significant effects between linear mixed models model comparisons are marked in bold. 
medRxiv preprint doi: https://doi.org/10.1101/2021.10.24.21265240; this version posted October 26, 2021. The copyright holder for this preprint (which was not certified by peer review) is the author/funder, who has granted medRxiv a license to display the preprint in

It is made available under a CC-BY-NC-ND 4.0 International license .

\section{Pre-registered secondary analysis}

To further investigate underlying physiological and psychological factors explaining the effects on hunger and mood overall and by meal category, we extended the main analysis and included macronutrient composition available in a subset of datapoints, taste ratings and additionally subdivided the dataset by gender and by dietary adherence (in the app study only). Also, we explored if random allocation to a meal, suppressing free choice, would mask any effects.

\section{Nutrient composition and satiety}

Macronutrients between meal categories were not significantly different for energy content and saturated fats, but significantly different for carbohydrates, sugar, fat and protein (all Wilcoxon $p$ $<0.01, \mathrm{n}_{\max }=1262$, Figure 4, SI Table 1), with higher carbohydrates, higher sugar, lower fat and lower protein for plant-based meals. The amount of protein, which was approximately one third lower in plant-based meals compared to animal-based meals (Figure 4F), had a small effect on post-meal satiety, i.e. that higher protein content led to higher satiety $(b=-0.01, t=-3.1, p=$ 0.002 ), which was not significantly different between meal categories (interaction effect, $p<0.89$ ). No further significant interaction effects of nutrients were found for the models on hunger and mood.

Analyses for fiber content as pre-registered could not performed, due to missing information on fiber content in all cafeterias. We therefore explored differences in meal composition / food components qualitatively in frequency plots of meal components and quantitatively by running models on carbohydrate quality (i.e. whole-grain vs. white flour meals). Overall, description of plant-based meals showed higher frequency of vegetables and salads, as well as other food items with high amounts of fiber, like whole grain, lentils or sweet potatoes, compared to animal-based meals. Further, when comparing identical meal descriptions (most common meal was "spaghetti bolognese") between white flour ( $n=416$ meals (animal-based: 317 , plant-based=99)) vs. wholegrain flour ( $n=26$ meals (animal-based: 2 , plant-based=24))), we found no significant differences between kcal and protein content (both $p>0.54$ ), and assumed higher fiber content for wholegrain meals. Accordingly, linear mixed models (LMMs) showed that hunger was lower $(b=-0.30$, $\left.t=-1.7, p<0.2 \times 10^{-15}\right)$ and mood was higher $\left(b=0.15, t=0.8, p<0.8 \times 10^{-7}\right)$ independent of timepoint for spaghetti bolognese made of whole-grain flour compared to white flour. Post-meal ratings did not differ for hunger $(b=-0.08, t=-0.28, p=0.78)$, mood was significantly increased after whole-grain meals $(b=0.41, t=1.98 p<0.05)$ (Figure 5 ). Comparisons between meal category were not possible due to limited group size for carbohydrate quality per meal category. 
medRxiv preprint doi: https://doi.org/10.1101/2021.10.24.21265240; this version posted October 26, 2021. The copyright holder for this preprint (which was not certified by peer review) is the author/funder, who has granted medRxiv a license to display the preprint in perpetuity.

It is made available under a CC-BY-NC-ND 4.0 International license .

A

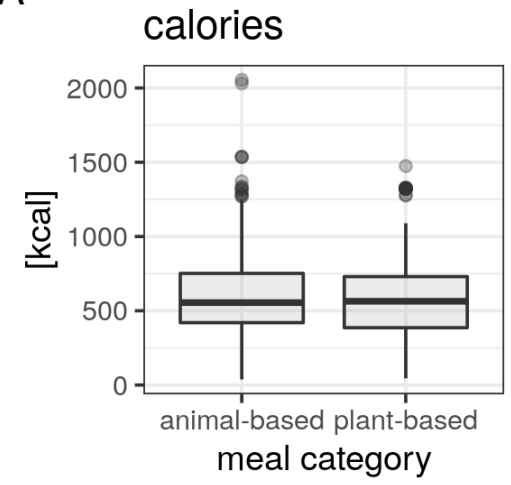

D

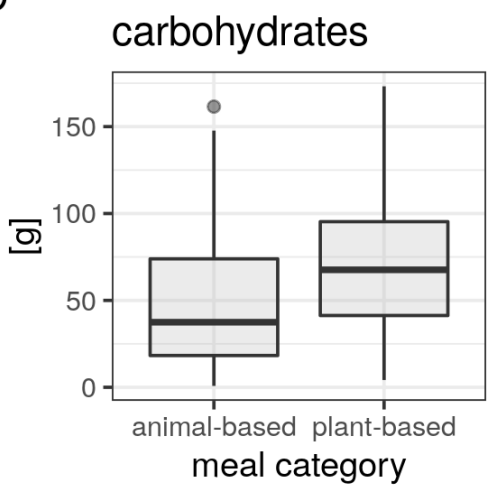

B

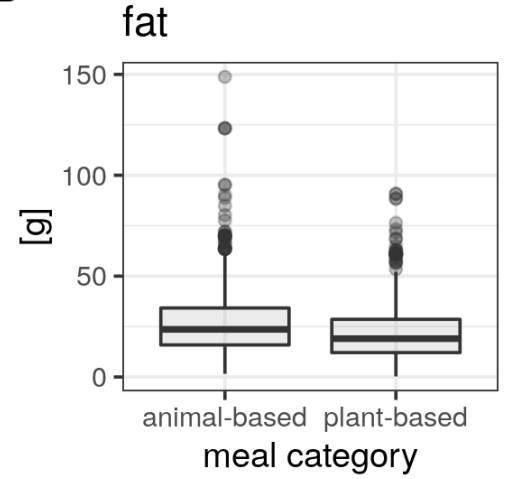

$E$

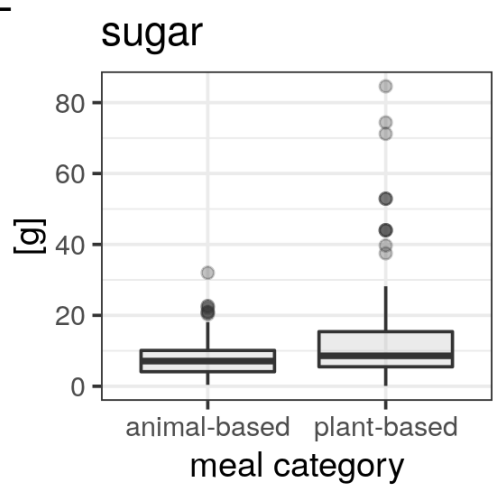

C sat. fats

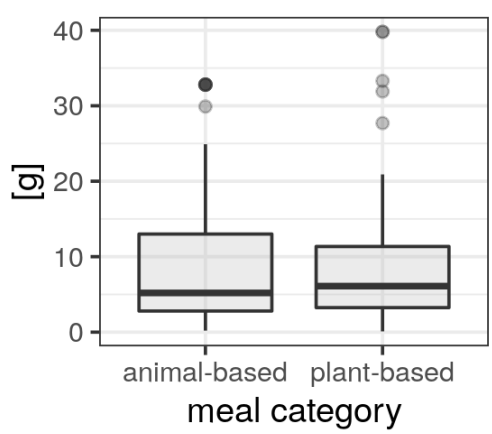

$\mathrm{F}$

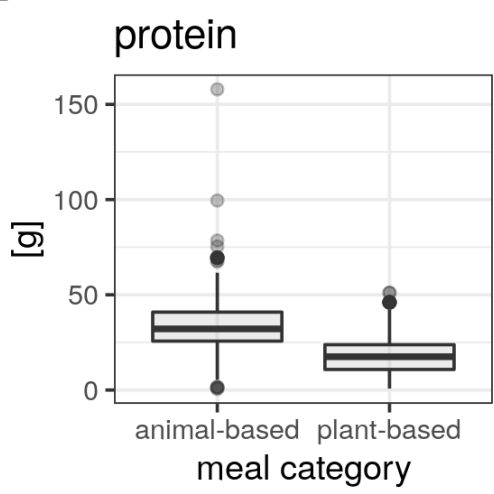

Figure 4: Nutrient composition between meal categories in a subsample of the app-study ( $n_{\max }=1262$, data from app study). Macronutrient information per portion size for A) calories in kcal B) fat in grams C) saturated fats in grams $D$ ) carbohydrates in grams $E$ ) sugar in grams and F) protein in grams. Median depicted as line, outliers (according to interquartile rule) as dots.

A

\section{hunger}

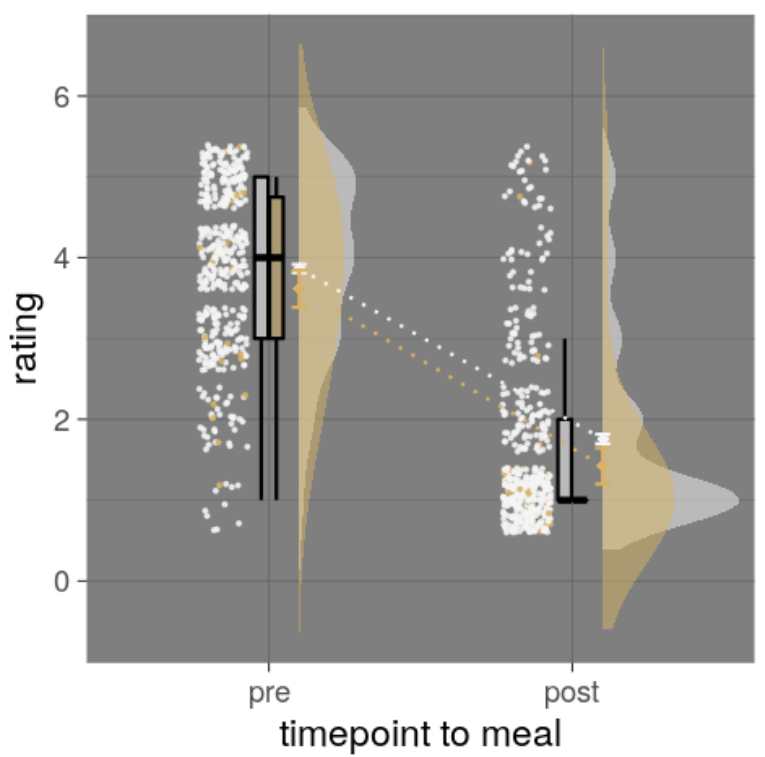

B

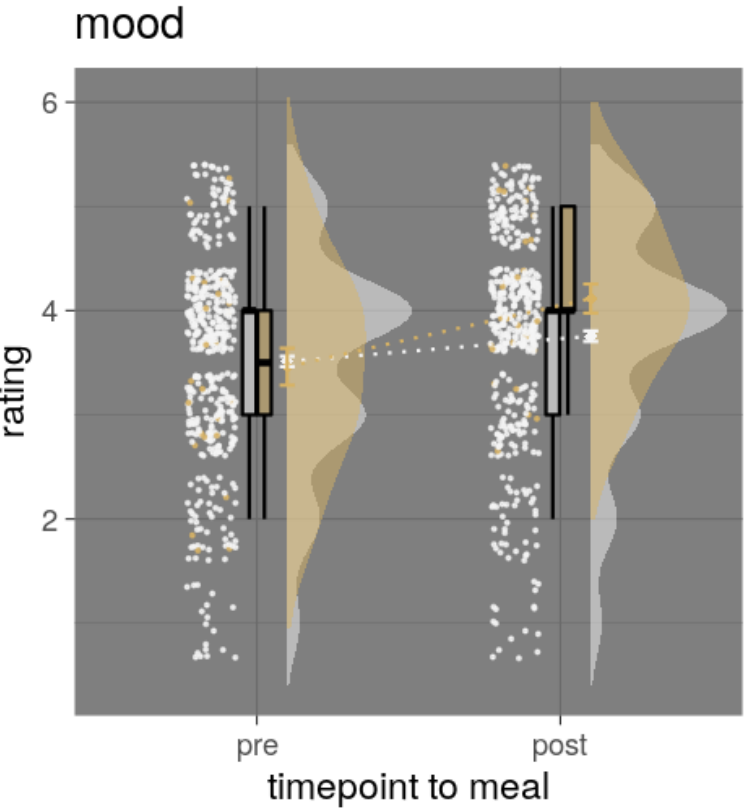

white-flour

whole-grain flour

Figure 5: Mean ratings of pre- and post-meal for hunger and mood by white flour vs. whole-grain flour bolognese meals (app-study only $(n=442)$ depicted in A) hunger B) mood. Median depicted as line, mean as dot, outliers (according to interquartile rule) as triangles. 
medRxiv preprint doi: https://doi.org/10.1101/2021.10.24.21265240; this version posted October 26, 2021. The copyright holder for this preprint (which was not certified by peer review) is the author/funder, who has granted medRxiv a license to display the preprint in

It is made available under a CC-BY-NC-ND 4.0 International license

\section{Effects of taste on hunger and mood independent of meal category}

Post-meal taste ratings provided on a Likert scale from one to five stars were available in the app study only and showed significant differences between meal categories, with animal-based meals being rated higher in taste more frequently (mean \pm SD: animal-based: $3.86 \pm 1.23$; plant-based: $3.77 \pm 1.27$, Kruskal-Wallis $x^{2}(1)=21.8, p<.001$, scale from one to five stars; zero stars for retracted rating, Figure 6).

According to LMMs, better taste was related to higher satiety and higher mood on average, with a somewhat linear relationship from lowest to highest taste category, in particular for post-meal mood ratings (Figure 6, SI Table 2). Note that only 4.9\% of individuals reported lowest taste ratings, and $2.4 \%$ retracted the rating (corresponding to zero stars), whereas $35.2 \%$ reported maximal ratings across all meals. Overall, low taste ratings increased hunger and high taste ratings lowered hunger considerably (post-meal ${ }^{*} 1$ star: $b=0.6, t=6.4$; post-meal ${ }^{*} 5$ stars: $b=-$ $0.5, t=-7.3$ ). Also, low taste ratings had a strong negative effect on post-meal mood (post-meal ${ }^{*} 1$ star: $b=-1.3, t=-19.8$ ), whereas high taste ratings moderately elevated post-meal mood (postmeal ${ }^{*} 5$ stars: $\left.b=0.5, t=8.5\right)$. This taste effect on hunger and mood was significantly different between animal-based meals compared to plant-based meals, showing a slightly stronger effect of taste on both hunger and mood after an animal-based meal (Figure 6: triple interaction between timepoint, meal category and taste: all betas $>|0.01|$, all $p<0.01)($ SI Table 2). 
medRxiv preprint doi: https://doi.org/10.1101/2021.10.24.21265240; this version posted October 26, 2021. The copyright holder for this preprint (which was not certified by peer review) is the author/funder, who has granted medRxiv a license to display the preprint in It is made available under a CC-BY-NC-ND 4.0 International license

A

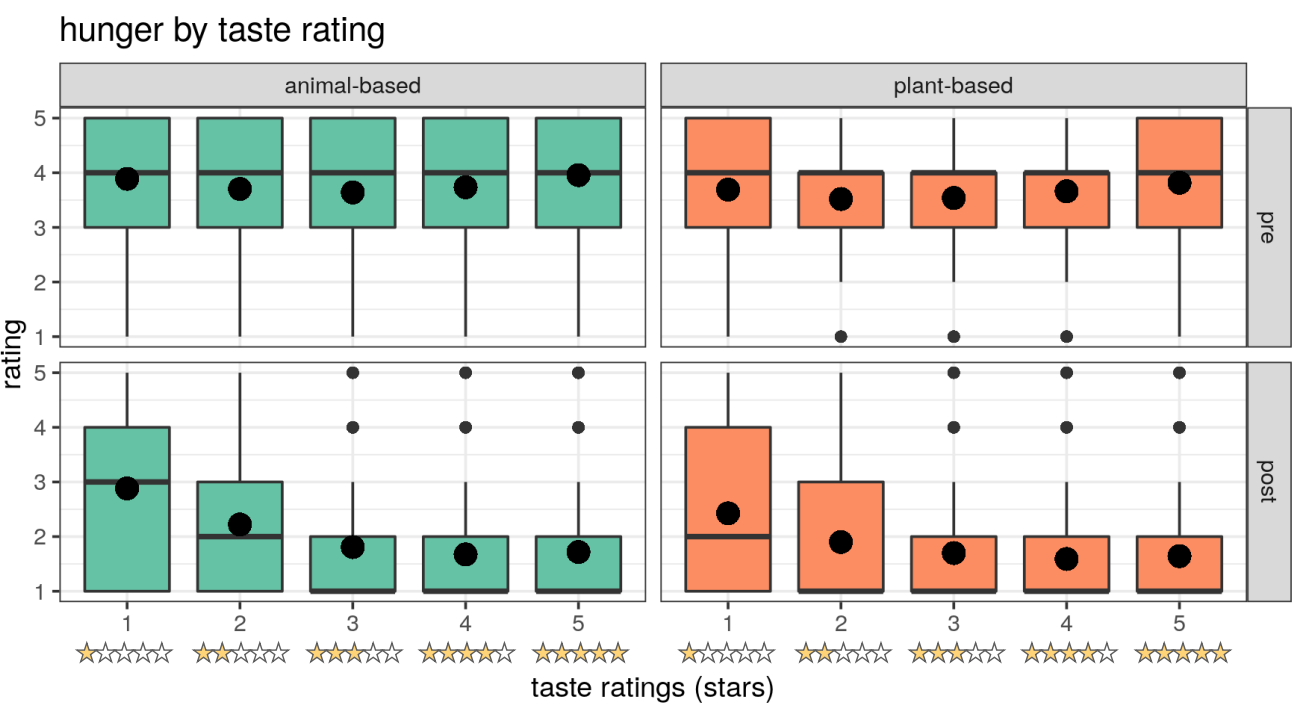

B

mood by taste rating
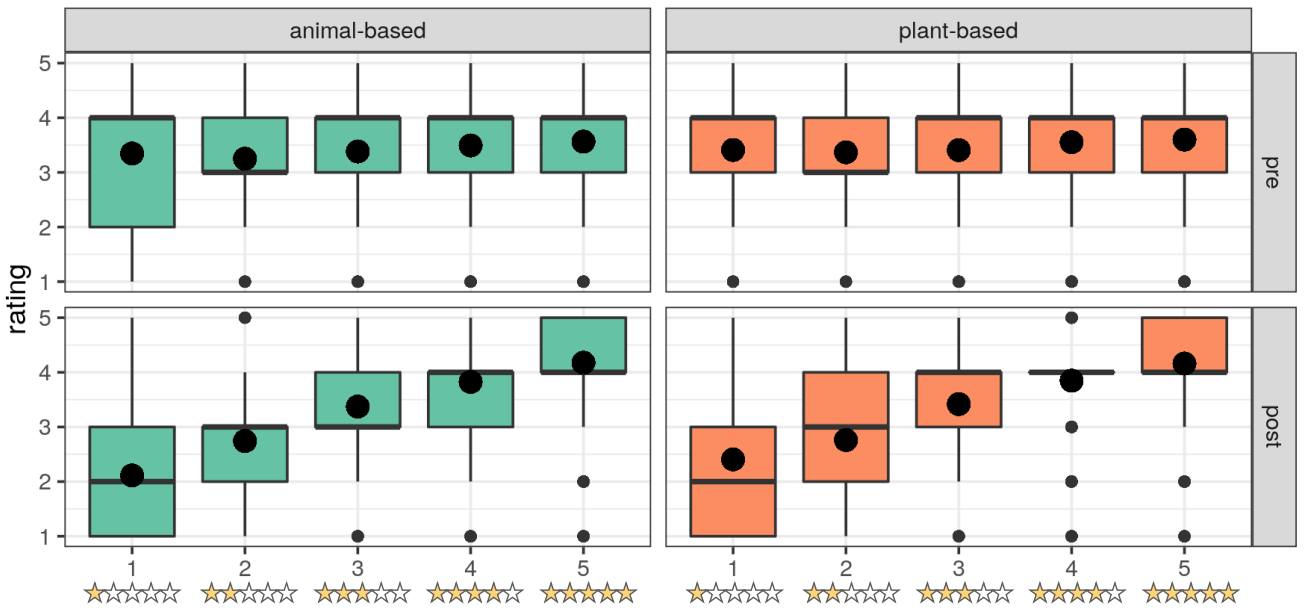

taste ratings (stars)

Figure 6: Effects of taste ratings on hunger and mood by star rating provided (app study only). A) Hunger ratings by taste rating from 1 to 5 stars B) Mood ratings by taste rating from 1 to 5 stars. Median depicted as line, mean as dot, outliers (according to interquartile rule) as small dots.

\section{Correlation of post-meal satiety, mood and stress}

Changes in satiety pre- to post-meal correlated with changes in mood pre- to post-meal, i.e. lower meal-induced hunger was associated with higher meal-induced mood, significant for data from the app study (Spearman's correlations 95\%Cl p-value; app study: $r=-0.19[-0.21-0.18] p<.001$; sub-study free choice: $r=-0.08[-0.230 .07] p=0.3$; sub-study randomized allocation: $r=0.13[-$ $0.100 .35] p=0.27$, Figure 7, SI Figure 5). There was no association between changes in hunger and stress levels (sub-study free choice: $r=0.15[-0.0040 .288] p=0.056$; sub-study randomized allocation: $r=-0.10[-0.320 .14] p=0.43$ ) in the two sub-studies. There was a significant correlation between lower mood and higher stress levels pre- to post-meal in both sub-studies (sub-study free choice: $r=-0.34[-0.46-0.20] p<0.001$; sub-study randomized allocation: $r=-$ $0.39[-0.57-0.17] p<0.001$, SI Figure 5). 


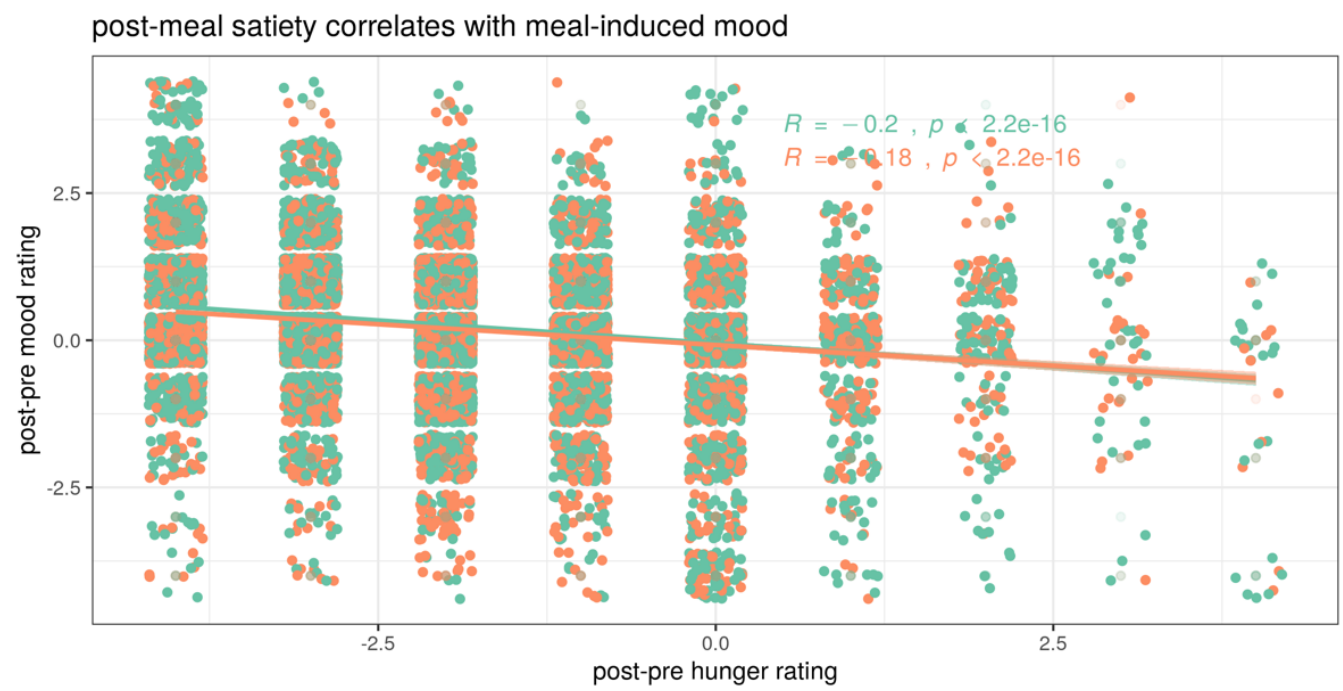

Figure 7: Correlation of post-pre changes between hunger and mood levels plotted by meal category (green: animal-based; orange: plant-based) (app study only). Spearman's correlation and $95 \% \mathrm{Cl}$ depicted.

\section{Confounding variables between meal categories: gender, social interaction, finishing a meal}

Plant-based meals were more frequently chosen by female and diverse gender, eaten alone and less often finished compared to animal-based meals (Table 1). To investigate the potential confounding effects of these factors, we repeated the main models for satiety and mood including these factors in separate models.

Overall, hunger was significantly different for gender, showing lower hunger in female $(b=-0.23$, $t=-15.6)$ and higher hunger in diverse $(b=0.21, t=4.0)$ compared to male gender (model comparison $p<2.2 \times 10^{-16}$, Figure 8A, SI Table 3). Mood in general was slightly lower in female $(b=-0.01, t=-0.9)$ and drastically lower in diverse gender $(b=-0.71, t=-13.8)$ (model comparison $\mathrm{p}<2.2 \times 10^{-16}$, Figure 8B, SI Table 3). When running gender-stratified LMMs (male $\mathrm{n}=8291$, female $n=7418$, diverse $n=279$ ), post-meal hunger after plant-based compared to animal-based meals was similarly higher for male $(b=0.07, t=2.2, p=0.03)$ and female $(b=0.09, t=3.0, p=$ 0.003 ) and not significantly different for diverse $(b=-0.08, t=-0.4, p=0.7)$. Models for post-meal mood were significant for both male and female (all $p<0.005)$, but not for diverse gender $(p=$ 0.08 ), with similarly lower mood ratings in both males and females (male: $b=-0.07, t=-2.8$; female: $b=-0.1, t=-4.1$, diverse: $b=0.35, t=1.8$ ) after plant-based vs. animal-based meals. Note, that taste ratings were similar across all genders (SI Figure 6). 
A

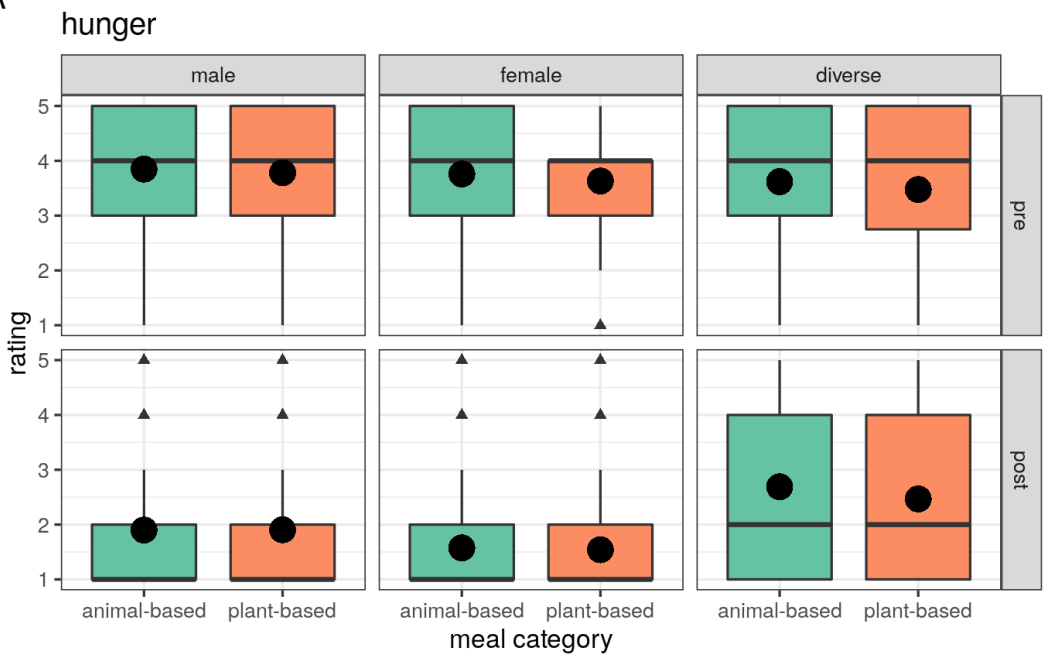

B

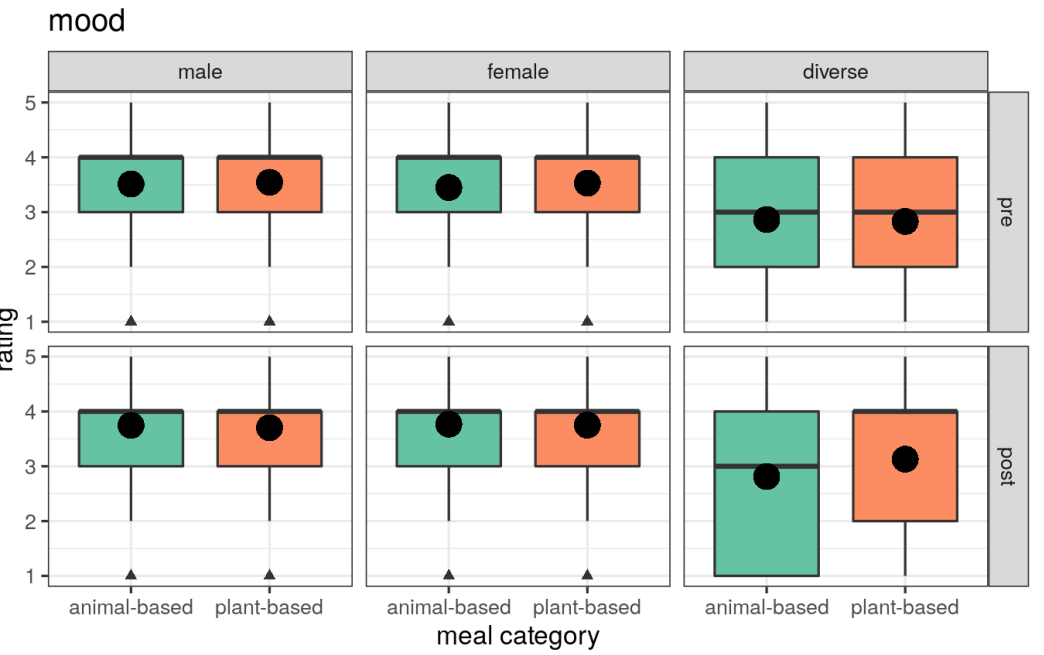

Figure 8: Effects of gender on hunger and mood (app study only, $\mathrm{n}_{\text {male }}=8291, \mathrm{n}_{\mathrm{female}}=7418$, $\mathrm{n}_{\text {diverse }}=$ 279). Median depicted as line, mean as dot, outliers (according to interquartile rule) as triangles.

Eating in company compared to eating alone was related to moderately higher hunger $(b=0.1, t$ $=6.1$ ) and higher mood $(b=0.1, t=6.4)$ (model comparison all $\left.p<2.1 \times 10^{-10}\right)$. Yet, social company during meal intake did not explain significant variance of post-meal ratings for hunger or mood by meal category (model comparison all $p<0.68$ ).

Finishing a meal was related to higher overall hunger $(b=0.1, t=5.4)$ and higher mood $(b=0.4$, $t=20.2$ ) (model comparison all $p<7.0 \times 10^{-8}$ ). Moreover, finishing a meal also explained slightly higher post-meal hunger ratings $(b=0.05, t=0.8)$ but also slightly higher mood $(b=0.08, t=1.6)$ for plant-based compared to animal-based meals (model comparison all $p<2.2 \times 10^{-16}$ ).

Although not different across meal categories, coffee intake was assessed as a potential confounder on satiety and mood ratings in sub-studies two and three (data was in subgroups only and not available for the app study). Coffee intake did not explain a significant variance on hunger or contentment, but higher coffee consumption was related to higher stress levels $(250-500 \mathrm{ml}: \mathrm{b}$ $=-0.17, t=-0.3 ; 500-1000 \mathrm{ml}: b=6.2, t=3.6$; note the limited sample size of $n=32$ ).

\section{Effects of impulsivity in meal choice}

In the app study, choosing a plant-based meal was $10 \%$ more often reported to be a planned decision, compared to that of an animal-based meal choice $\left(X^{2}=174, p<2.2 \times 10^{-10}\right.$, planned 
medRxiv preprint doi: https://doi.org/10.1101/2021.10.24.21265240; this version posted October 26, 2021. The copyright holder for this preprint (which was not certified by peer review) is the author/funder, who has granted medRxiv a license to display the preprint in

It is made available under a CC-BY-NC-ND 4.0 International license.

plant-based $=72 \%$, planned animal-based $=62 \%$, Table 1 ). Moreover, we observed an interaction effect between the feeling of planned decision-making at meal choice on higher hunger $(b=0.04, t=2.8, p=0.006)$ and higher mood $\left(b=0.13, t=8.9, p<2.2 \times 10^{-16}\right)$ after the meal. The interaction effect of a planned decision on higher hunger at post-meal was significantly lower for plant-based meal choices (decision*post-meal* plant-based: $b=-0.04, t=-0.9, p<2 \times 10^{-5}$ ), as well as less pronounced for lower mood (decision*post-meal ${ }^{*}$ plant-based: $b=-0.02, t=-0.4, p<5 \times 10^{-}$ ${ }^{6}$ ) compared to animal-based meals.

\section{Contentment when randomized to meal}

In sub-study three meal choice was randomly allocated and therefore not a confounding variable. Meal category was randomly assigned after filling out pre-questionnaires right before the planned meal. Contentment about randomization before the meal was not significantly different for animalbased versus vegetarian or vegan meals $\left(n=71, X^{2}=9.6, d f=9, p=.27\right.$, Figure 9A). Overall post-meal contentment after randomization was met more frequently for the animal-based condition ( $n=71, X^{2}=6.1, d f=2, p=.04866$, Figure 9B). Those who reported to be content with the randomization, did not differ between reasons for it ("chosen anyway", "preferred something else, but I liked it", "generally no preference", $X^{2}=0.03$, df $=2, p=.98$, Figure 9C), compared to those who reported discontent $\left(n=8\right.$ "preferred vegan", $n=9$ "preferred meat-based", $X^{2}=13.2$, $\mathrm{df}=1, \mathrm{p}<0.001$, Figure 9D). However, randomization contentment pre- and post-meal as a main factor did not explain a significant amount of variance with regard to satiety or mood (all betas < 0.28 , model comparisons all $p>0.52$ ).

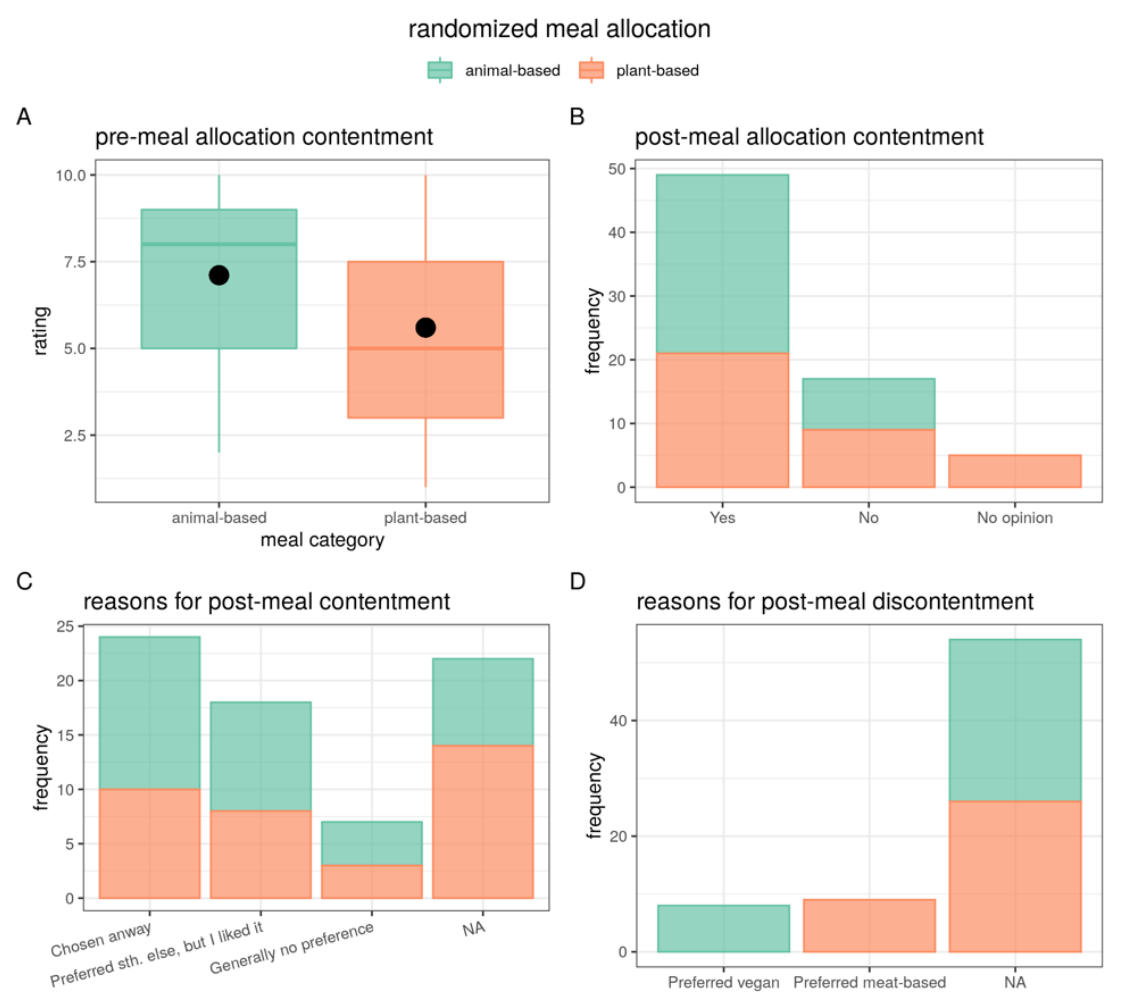

Figure 9: Post-randomization contentment and post-meal contentment and reasons for the latter (substudy $2, n=71)$. A) Pre-meal allocation contentment rating (1-10 Likert scale) by meal category. Mean depicted as dot. B) Post-meal allocation contentment in categorical answers depicted as frequency by meal category. C) Reasons for post-meal contentment in categorical answers depicted as frequency by meal category. D) Reasons for post-meal discontentment in categorical answers depicted as frequency by meal category. 
medRxiv preprint doi: https://doi.org/10.1101/2021.10.24.21265240; this version posted October 26, 2021. The copyright holder for this preprint (which was not certified by peer review) is the author/funder, who has granted medRxiv a license to display the preprint in It is made available under a CC-BY-NC-ND 4.0 International license .

Further, we tested the effect of assigned meal and subsequent liking as preregistered by defining three categories, namely voluntary $(n=174)$ vs. non-voluntary-liked $(n=49)$ vs. non-voluntarydisliked $(n=17)$ of meal category across both sub-studies two and three. Mode of choice did not explain any significant variance on hunger, mood or stress levels across time on meal choice (preregistered model: all $p>0.14$ ). When looking at interaction of timepoint and mode of choice and meal category, post-meal hunger was higher for non-voluntary-liked $(b=1.4, t=1.8)$ and lower for non-voluntary-disliked $(b=-1.6, t=-1.4)$ compared to voluntary choice for plant-based meals (model comparison $p<0.004$ ). Post-meal effects of mode of choice for plant-based meals showed higher mood for non-voluntary-liked $(b=0.34, t=0.5)$ compared to non-voluntary disliked $(b=-0.7, t=-0.7)$ (model comparison $p=0.028$ ). There was no interaction effect of mode of choice on stress levels post-meal for plant-based meals $(p>0.9)$.

\section{Dietary habits - subgroup analysis}

To account for potential effects of dietary adherence, we repeated the analysis in subgroups for omnivorous $(n=11,600)$, vegetarian $(n=3,456)$ and vegan $(n=911)$ dieters.

The analysis in predominantly omnivorous dieters only presented the same effects as the whole group, i.e. showing slightly lower mood after a plant-based meal compared to animal-based meals, and also significantly higher post-meal hunger ratings for those choosing plant-based meals (SI Table 4). Influences of taste remained significant for post-meal mood, yet the influence of taste ratings on hunger by meal category was no longer significant.

For predominantly vegetarian dieters only, results again resembled the main analysis, with no effect on post-meal hunger, yet lowered mood for those choosing a plant-based meal (note the unequal group size of animal-based meal $n=577$, plant-based meal $n=2,880$, SI Table 4). When accounting for taste ratings, post-meal hunger was lower overall for meals rated with five stars, yet hunger was higher when this was a plant-based meal. Mood ratings showed a similar paradoxical effect when adjusted for taste, namely improved mood for liked meals, yet when those were plant-based, mood was lowered.

For predominantly vegan dieters only, hunger was lower and mood was higher after choosing a plant-based meal (note the unequal group size of animal-based meal $n=117$, plant-based meal $n=795$ out of 911 vegan dieters, SI Table 4). When accounting for taste, highly liked meals reduced hunger, yet there was no difference in hunger ratings between meal categories. Mood adjusted for taste, showed improved mood for highly liked meals, which was also shown for plantbased meals compared to animal-based ones.

Taste ratings by meal category differed for dietary adherence groups, namely that animal-based meals were rated higher compared to plant-based meals by omnivores (animal-based: $3.87 \pm 1.2$, plant-based: $3.70 \pm 1.3$ ) and similarly, but less pronounced for vegetarians (animal-based: $3.88 \pm 1.2$, plant-based: $3.81 \pm 1.7$ ). The opposite was true for vegans (animal-based: $3.34 \pm 1.7$, plant-based: 3.96 \pm 1.2 ) (SI Figure 7).

\section{Time stamps}

Time difference between pre- and post-meal hunger entries in the app study varied quite drastically and was very small on average (mean \pm SD: $54 \pm 139$ min, median: 0.5 min). To restrict entries to a reasonable timeframe around actual food intake, we additionally restricted the analyses as preregistered to entries that had more than 5 min and up to $3 \mathrm{~h}$ time lag between pre- and post-meal (hunger) entries (liberal timeframe) or more than $20 \mathrm{~min}$ and up to $1.5 \mathrm{~h}$ time 
medRxiv preprint doi: https://doi.org/10.1101/2021.10.24.21265240; this version posted October 26, 2021. The copyright holder for this preprint (which was not certified by peer review) is the author/funder, who has granted medRxiv a license to display the preprint in It is made available under a CC-BY-NC-ND 4.0 International license .

lag between pre- and post-meal (hunger) entries (conservative timeframe). This led to a profound drop in sample size (liberal $n=3725$, conservative $n=1878$ ).

Results remained largely unchanged for the liberal timeframe from $5 \mathrm{~min}$ to $3 \mathrm{~h}$ difference between pre- and post-meal entries, namely significant main effects of post-meal timepoint with lower hunger and higher mood. For interaction effects of post-meal by meal category, no significant effects were found for hunger or mood, yet nominal differences were similar to the main analysis for hunger (higher post-meal hunger for plant-based meals), but not for mood (higher post-meal mood for plant-based meals). For the more conservative timeframe from 20 min up to $1.5 \mathrm{~h}$ postmeal, main effects for lower hunger and higher mood for post-meal timepoint were sustained. Yet, interaction effects of timepoint by meal category showed significant higher post-meal hunger for those choosing a plant-based meal $(b=0.14, t=2.3, p=0.024)$, while the main analysis showed non-significant results in the same direction of the estimate, and no significant effect on post-meal mood, yet also similar nominal differences with lower mood after plant-based meals $(p>0.14)$. Note that the reduced sample size when curating for timeframe indicate that the remaining entries had quite a high variety of time lag related to meal intake. Compliance with study design specific timeframes was manually curated in sub-studies 2 and 3 and have already been considered in all of the above analyses.

\section{Discussion}

In this series of large-scale online surveys of $>16,300$ individual data entries and three independent data collections in German cafeterias, we provide evidence based on pre-registered analyses that the category of a single meal (i.e. whether plant-based or containing meat/fish) exerts no effect on post-prandial hunger of the individual, and a certain, yet not considerably large influence on mood. More specifically, we found that while participants report higher satiety and improved mood after a meal in general, mood was slightly higher in individuals choosing a plantbased meal before the meal. Against our hypotheses, there was no significant interaction effect of meal category and timepoint for hunger, but for mood, however contrary to our hypothesis, with smaller post-meal increases in mood for individuals choosing a plant-based meal compared to an animal-based meal. The more deeply phenotyped sub-studies 2 and 3, profoundly smaller in sample size, indicated similar nominal differences between meal categories, yet did not support that those differences should be regarded statistically significant in the main pre-registered analyses.

\section{Effects of nutrient composition on hunger}

We hypothesized that plant-based meals would increase satiety due to a higher amount of fiber in those meals, which was however not supported by the data. This might imply that fiber content has only negligible effects on satiety, and/or that fiber was not different between meal categories on average. In addition, while we could not evaluate actual fiber content due to missing information, we found that plant-based meals had higher carbohydrate, higher sugar, lower fat and lower protein content compared to animal-based meals in a subset of available datapoints. This is insightful given that plant-based food consists of more carbohydrates, while meat and fish have more protein. Now, in a secondary analysis, we found that protein content contributed to satiety after the meal, arguing that plant-based vs. animal-based meals could relate to lower satiety due to the difference in protein content between meal categories, thereby concealing (potential) effects of higher fiber content on satiety. Indeed, cross-over within-subject studies reported that post-meal satiation did not differ dependent on protein source when adjusted for 
medRxiv preprint doi: https://doi.org/10.1101/2021.10.24.21265240; this version posted October 26, 2021. The copyright holder for this preprint (which was not certified by peer review) is the author/funder, who has granted medRxiv a license to display the preprint in

It is made available under a CC-BY-NC-ND 4.0 International license.

fiber content [26] or in case of protein preload previous to ad libitum food intake [27]. Moreover, cafeteria meals overall might contain more processed and less balanced nutrient compositions compared to the average plant-based meal investigated in previous literature. However, note that highly processed vegan meals, still four times higher in fiber, were also found to induce higher satiation in a within-subject randomized clinical trial compared to energy-matched meatcontaining processed meals [28]. Another explanation for the lack of strong differences between meal categories might be that individuals choosing animal-based meals added fiber-rich side dishes such as broccoli, thereby "bypassing" the hypothesized disadvantageous effect of animalbased meals on post-meal hunger ratings. Notably, participants choosing plant-based meals reported less hunger overall compared to those making animal-based choices, which might have led to a certain ceiling effect on the 5-point Likert scale in the app study so that satiety could not be achieved in similar magnitude between meal categories. Future studies could avoid this phenomenon through implementing a more controlled environment with e.g. a 12 h-fasting condition before the meal and thus comparably higher hunger before the meal. However, our large-scale analysis offers the advantage to study effects of a single meal in a real-world context. Thus, while participants choosing a plant-based meal in cafeterias were not more satiated by their current (fiber-rich) meal, they appeared less hungry on average, which might relate to more longterm effects of differences in dietary habits (see below). However, these considerations remain highly speculative given the timeframe of our study design.

\section{Effects of meal category on mood}

Against our hypothesis, that plant-based meals would increase post-meal mood more strongly than animal-based meals, we found the opposite effect. Here, we might have neglected certain normative expectations towards the meal in a society that on average consumes meat and fish on a daily basis [29], in particular potential reservations against plant-based meals related to be lacking in something or not being hearty enough, which is also in line with in lower taste ratings of plant-based meals. These expectations might have influenced post-meal mood ratings. Surprisingly, individuals choosing plant-based meals showed higher mood ratings before the meal, which is in contrast to meta-analytical evidence for higher depressive symptoms in longterm vegetarian/vegan dieters [18], but in line with improved mood related to pre-/probiotic diets [19]. Note, that the short timeframe of a single-meal on mood ratings compared to epidemiological evidence of long-term dietary habits could explain the deviating results, and that the effect size of the present study must be considered small. Further, fiber-induced improvements on mood could be particularly effective for vulnerable individuals only, as shown for patients suffering from inflammatory bowel syndrome or major depressive disorder [20,30]. While we assume that the majority of individuals was healthy in our studies assessing detailed medical history was out of scope in the presented online studies. Besides meal category, taste ratings showed a substantial impact on post-meal mood ratings, with higher mood for more tasteful meals. Importantly, as plant-based meals were ranked less tasty overall, especially by omnivores and vegetarians, cafeterias should aim to improve tastiness of plant-based meals in order to ensure equal enjoyment and satisfaction despite meal category. When limiting the analysis to identical meal descriptions such as spaghetti bolognese, note that those providing higher fiber content through whole-grain pasta induced higher satiety and higher mood compared to conventional pasta.

\section{Acute vs. long-term effects of plant-based meals}

The present acute effects are somewhat in contrast to epidemiological evidence showing higher satiety and both either higher or lower depressive symptom scores in vegan/vegetarian dieters $[18,20,31]$, we did not observe higher satiety and mood at post-meal for plant-based meals. In dietary adherence subgroup comparisons we found that lower satiety and lower mood at post- 
medRxiv preprint doi: https://doi.org/10.1101/2021.10.24.21265240; this version posted October 26, 2021. The copyright holder for this preprint (which was not certified by peer review) is the author/funder, who has granted medRxiv a license to display the preprint in

It is made available under a CC-BY-NC-ND 4.0 International license .

meal for plant-based choices occurred in the omnivorous and vegetarian group only, yet effects were inverse for the vegan subgroup. This could be due to the limited timeframe of the intervention only looking at acute postprandial changes in satiety and mood after a single meal in contrast to long-term dietary habits in epidemiological studies, that might be better suited to capture changes in gut-brain signaling and host physiology in response to higher fiber intake. A systematic review further highlights that although fiber indeed leads to satiety-inducing effects, the expected timeframe of action is rather 3 to 15 hours post-ingestion [14]. Indeed, it has been shown that diet can rapidly change host gut microbiome, yet these changes only occur within 24 to 72 hours after drastic dietary changes [32]. Also, we found that individuals choosing a plant-based meal showed lower overall hunger and higher mood before the meal compared to animal-based meals. In sum, these findings underline that contrary to our hypothesis, not the acute meal choice, but rather habitual dietary patterns and other characteristics such as dietary adherence may determine the effects of a meal.

\section{Importance of perceived taste, meat tradition and deliberate decision-making}

Considering biopsychological mechanisms, taste ratings, which were overall slightly higher for animal-based meals, had a strong effect on satiety and mood, highlighting that taste shapes satiety and mood acutely after a plant-based meal and even more so after an animal-based meal. It has been shown that omnivorous individuals expect plant-based alternatives to be less tasty compared to a meat burger [33]. While impulsive decisions were more frequently made for animalbased meals, such a spontaneous decision further augmented the effect of taste on satiety and mood as shown by out data, whereas in plant-based meal eaters planned decisions had less effect on hunger and mood. Taste have also been shown to influence post-meal satiety [37, 38], with greater satiation for tasteful meals independent of nutrient composition. Thus, while macronutrients dense in calories such as fat are often described as flavor carriers, and shown to elicit even supra-additive value if paired with carbohydrates on a neuronal level [39], low-calorie meals such as salad bowls may induce similarly strong satiety like mac'n'cheese if perceived similarly tasty. However, interoceptive signaling via emotion regulatory processes might determine the properties of any given food further, which may partly explain why some (often high-caloric) foods, such as pizza or burgers, are considered emotionally comforting and rewarding [40]. Notably, besides the subjective component of taste, there could have been an objective difference in taste by meal category. Meat- and fish-based meals might have been higher in quality due to a longer tradition and knowledge of meal preparation for such [34] compared to rather recent developments of vegan and vegetarian cuisine in Germany, that is barely taught in conventional cooking trainings. Moreover, societally meat dishes are viewed as more valuable and might therefore have a higher intrinsic value for omnivorous eaters in meatheavy culinary traditions [35], one of the many reasons why despite wanting to eat more sustainably only some groups succeed in avoiding meat completely, so called flexitarians [36]. Considering the university setting, choosing meat-based meals could also be motivated by maximizing food reward linked to expected taste for meaty meals. Although we did not evaluate meal price in this study, oftentimes in cafeterias plant-based meals subsidize animal-based meals leading to equal or even lower prices for meaty meals. Yet, in our analysis socioeconomic status was not a significant predictor of meal choice. Indeed, we also found that hunger and mood changes are not completely independent, but that higher meal-induced satiety correlated with stronger mood improvements.

\section{Effects of gender, finishing a meal and social interaction}

Moreover, gender and whether the individual finished their meal or not could explain a high share of hunger and mood rating differences, whereas social interaction during meal time was not explanatory of post-meal hunger and mood ratings. Female and diverse gender showed 
medRxiv preprint doi: https://doi.org/10.1101/2021.10.24.21265240; this version posted October 26, 2021. The copyright holder for this preprint (which was not certified by peer review) is the author/funder, who has granted medRxiv a license to display the preprint in

It is made available under a CC-BY-NC-ND 4.0 International license .

differential effects on hunger and mood ratings related to general meal intake, yet for post-meal ratings for plant-based meals females and males showed similar effects for lowered mood, yet this effect was not present in diverse gender (however note the small sample size for diverse in comparison). Indeed psychological mechanisms of food intake differ by gender, i.e. females score higher on unhealthy eating traits [42], show higher prevalence of eating disorders, body and shape concerns [43], are more frequently and more strictly on plant-based diets [44], follow restrictive diets and weight loss strategies more often, as well as having an increased awareness for health $[45,46]$. Only few studies considered gender diverse individuals, yet some evidence supports a heightened risk for eating disorders in sexual and gender diverse students [47]. In sum, these findings underline the importance of designing gender-sensitive public health strategies with regard to diet, e.g. tailoring differences in health awareness, mood and emotion regulation and openness to plant-based meals to the individual.

\section{Manipulating mode of choice}

Even though contentment about meal category at time of being informed about randomization was not different between meal groups, post-meal contentment about the allocation differed, with more participants reporting that they would have preferred an animal-based meal when they were dissatisfied with the allocation. Yet, hunger and mood ratings remained unaffected, highlighting that individual preference for category per se did not affect satiety and mood that much. However, when meal category was randomly allocated hunger and mood seemed to be higher when the meal was liked, and both were lower when disliked, showing opposite effects in this study setting compared to the free choice setting. This indicates that a forced choice might enhance the importance of the subjective liking of a certain meal category on hunger and mood, a notion that can inform policy-making when aiming to increase plant-based dieting.

\section{Dietary adherence might explain potential differences regarding internal beliefs and mindset}

Subgroup analysis suggests that in particular self-reported predominantly omnivorous and vegetarian dieters are driving the observed interaction effects of meal category on mood but also on hunger in the subsample analysis, whereas effects in vegan dieters were reversed. This underlines the potential confounding of (presumed) expectations towards plant-based meals when being able to deliberately choose between animal-based and plant-based meals. Possibly, food decision-making in non-vegan dieters might not rely on self-set dietary goals as much and reservations about plant-based meals could be further fueled by an unknown food composition or ingredients or unfamiliar taste. For vegan dieters meal choice is anyhow limited and food decision-making might rely on more long-term goals including health, ethical, and climate arguments [48], all of which are not immediately to be processed at time of meal choice. Indeed, literature shows that vegan and vegetarian diets are associated with orthorexia nervosa, an eating disorder with an obsession for healthy eating [49]. Unexpectedly, in sub-study two with omnivorous dieters only we also found higher scores for cognitive restraint and hunger in those choosing plant-based meals. Overall well-being or emotional constitution were not assessed in the app study though. In sum, dietary adherence factors could have masked or distorted potential effects of meal category on hunger and mood, indicating that other factors than single meal choice exert again considerably stronger influence.

\section{Limitations and strengths}

Online studies are gaining momentum, in particular hosted on crowdsourcing platforms, and have great potential in terms of collecting big datasets from the real-world [50]. Yet, several challenges in our study design should be noted as limitations:

Firstly, all results were based on self-reported subjective ratings and we expected compliance by the participants with the study set-up, yet fake ratings could not be excluded. The virtual setting 
medRxiv preprint doi: https://doi.org/10.1101/2021.10.24.21265240; this version posted October 26, 2021. The copyright holder for this preprint (which was not certified by peer review) is the author/funder, who has granted medRxiv a license to display the preprint in

It is made available under a CC-BY-NC-ND 4.0 International license .

and a resulting lower commitment to complete the study might also explain relatively large amounts of missing values for some of the confounding variables. Moreover, nutritional values were only available in a subset of data, further limiting power in the respective analyses. Note, that information on fiber content was not available, which might be due to a general lack of awareness and literacy on dietary fiber ("knowledge fiber gap", compare [51]), to which end we advocate to extend nutrient labeling on food packaging, in menus, in nutrition apps and nutritional experimental databases etc. by dietary fiber. Further, online datasets require careful data curation strategies, including exclusion of duplicates, defining outliers, fake and non-compliant entries. Notably, when restricting our analysis to a pre-defined still liberal or conservative timeframe around meal intake when entries needed to have been made, sample sizes were drastically reduced and smaller differences did not reach significance anymore, somewhat limiting our conclusions. To overcome this issue, future app studies might implement a technical solution that reminds participants to stick with certain time frames. Also when cooperating with already existing institutions and technological environments, the research team has to adapt to limitations or peculiarities of the dataset such as missing information or unusable data structures and should thus a priori consider how this would affect statistical analyses. Secondly, Likert scales were conceptualized and adapted to the virtual setting, making the use of established research tools difficult, but instead calling for new solutions and ideas for developing suitable, reliable research tools (such as emoji-based Likert scales). Thirdly, meal categorization into animal-based vs. plant-based was based on provided information by the cafeteria meal plans on allergens and meal description using keywords for classification. Manual categorization was only done in substudies 2 and 3 . Therefore, only unambiguously classified meals could be included, leading to a reduction in sample size. Fourthly, we did not assess important psychological factors that might have influenced meal choice, in particular, health awareness, dieting goals, sport habits and ethical concerns.

Besides the listed limitations, the presented studies have several strengths:

Firstly, the real-life experimental setting of all three studies is a major strength aiming to enhance application and conclusions to the living population without being in a highly controlled research environment. Secondly, especially the app study consists of a huge sample and has been collected nation-wide in Germany and partly in Austria increasing generalizability of the results independent of cafeteria location or regional differences. Also sub-studies 2 and 3 , although lower in sample size, are thoroughly phenotyped datasets with a multitude of potential confounders assessed. Thirdly, all studies are longitudinal and contain pre- and post-measures that allow linear mixed effects modeling correcting for the individual participant and the respective cafeteria location. Fourthly, addressing the complexity of real-life settings, various confounding factors were assessed and included in exploratory analyses to enhance the understanding of multimodal influences on meal decision-making and subsequent hunger, mood and stress ratings. Lastly, all three datasets have been carefully curated and sanity checks have been performed to ensure reliability of virtually collected ratings.

\section{Conclusion \& Outlook}

In summary, this series of large-scale surveys showed that overall effects of single plant-based meals compared to animal-based meals on satiety and mood are rather small compared to main effects of timepoint, underlining that meal category only has a minor impact. This notion alleviates some of the reservations against plant-based meals potentially not being satisfying enough or not leading to fullness, in modern societies [52]. Protein content and taste of meals were shown to contribute to satiety and mood. Thus, they should be increased in university cafeterias, in particular for plant-based meals, in order to enhance satisfaction and lastly also acceptability and prevalence of those meals that are regarded climate-friendly. Increasing plant-based choices 
medRxiv preprint doi: https://doi.org/10.1101/2021.10.24.21265240; this version posted October 26, 2021. The copyright holder for this preprint (which was not certified by peer review) is the author/funder, who has granted medRxiv a license to display the preprint in

It is made available under a CC-BY-NC-ND 4.0 International license

remains an important societal task with the aim to improve not only individual but also planetary health [53]. Moreover, promoting plant-based offers and increasing the proportion of plant-derived ingredients through science communication and the above discussed mechanisms might help to counter the rising obesity epidemic, particularly by replacing Western(-ized) diets. It should be noted that meals containing more plant-derived components are not necessarily healthier, as fast and ultra-processed foods, such as in meat or dairy substitutes that are becoming more prevalent, oftentimes have similar or worse nutrient composition.

Overall, animal-based vs. plant-based meal category has only minor influence on post-meal satiety and mood in university cafeterias compared to other demographic and external factors influencing meal choice. Future longitudinal studies, for example using smartphone-integrated real-world big data sampling are warranted to further understand the acute and long-term determinants of healthy food choices, possibly also assessing internal beliefs related to food decision-making.

\section{Materials and methods}

\section{Recruitment}

The Ethics Committee of the Medical Faculty of the University of Leipzig approved the study protocol and all participants provided written informed consent. The study was divided into three sub-studies and pre-registered at https://osf.io/a7yts (28 Nov 2019).

\section{Study design}

For the first sub-study, all users of the smartphone app iMensa and Mensaplan (provided in Germany, Austria, Switzerland by AIMPULSE Intelligent Systems GmbH, Bremen, Germany) were invited to take part in a brief survey consisting of 12 questions. The app has been originally developed to provide meal plan information and collect meal ratings of student cafeterias (mostly run by the local "Studierendenwerk") with approximately 300,000 users and about 5,000 ratings per week. Users were asked to report hunger and happiness before and after consuming a meal on a 5-point Likert scale each, accompanied by the originally app-provided rating of the respective meal on a 5-star scale. For the additional study-specific questions, emoji-based 5-point scales (Figure 1) were used to increase user-friendliness and to blend into the technological interface, selected based on maximal ratings on comprehension of the respective measure of interest in a pilot study (hunger: $n=29,45 \%$ approval for emoji "plate"; mood: $n=30,47 \%$ approval for emoji "smileys"). In addition, we asked for meal decision (spontaneous or planned), gender (female, male, diverse), usual predominant dietary habits (omnivorous, vegetarian, vegan) ("Which dietary pattern do you adhere to predominantly?"), amount of liquid intake in the last 2 hours $(<0.5 \mathrm{~L},<$ $1 \mathrm{~L},>1 \mathrm{~L}$ ), whether they ate alone or in company, whether they finished their meal or not, frequent smartphone use during the meal (yes or no), and sleep quality of the last night (good, normal, bad). All data was provided with anonymous user identifiers by the app provider, along with exact date and time stamps of each question. The specifics to the app study (compared to sub-studies $2+3$ ) were 1) both omnivorous and vegetarians/vegans took part in the study, no non-voluntary meal choice has been performed, 2) mood was asked with "how happy are you today ..."?, 3) the study did not assess stress levels and 4) meal categories were specified based on the available information provided by the cafeterias. 
medRxiv preprint doi: https://doi.org/10.1101/2021.10.24.21265240; this version posted October 26, 2021. The copyright holder for this preprint (which was not certified by peer review) is the author/funder, who has granted medRxiv a license to display the preprint in It is made available under a CC-BY-NC-ND 4.0 International license .

In the second and third sub-studies, all visitors of the student cafeterias in Leipzig, Berlin, Halle and Jena who planned to have lunch on-site, were over 18 years old and who had access to a LimeSurvey www.survey3.gwdg.de via a mobile device could take part in the study. Before eating a meal, a baseline survey served as a screening tool to exclude visitors reporting known food allergies, food intolerances, eating disorders, neurological and/or psychiatric disorders, and other diseases that may have an effect on diet and mood like depression, schizophrenia, multiple sclerosis or Crohn's disease. Also, vegetarians and vegans were excluded for better comparability of meal categories among omnivorous subjects and to enable random allocation to meals for the third sub-study. Participants were free to choose the day of the study.

In the next pre-meal survey, participants were asked to rate satiety, happiness and contentment on a 10-point Likert scale (Figure 1, before either freely choosing a meal (sub-study 2) or being randomly assigned to eat a animal-based or a plant-based (vegetarian or vegan) meal (sub-study 3). After finishing the meal, participants were instructed to again report satiety, happiness and contentment on the same 10-point Likert scale. Moreover, age, sex, height (in $5 \mathrm{~cm}$ categories) and weight, as well as net monthly income $(<500 € / 500-1000 € / 1000-1500 € / 1500-2000 € / 2000$ $2500 € />2500 €$ ) were assessed. In addition, a) estimated portion size, b) whether the meal was fully eaten up or not (yes/no), (c) whether side dishes or desserts have been chosen, (d) a questionnaire on eating habits (Food Frequency Questionnaire (FFQ), DEGS-1 [54]), e) a personality inventory (NEO-FFI) [55] and f) a questionnaire on eating habits (TFEQ) [42]. In addition, the survey asked about social contact during lunch (Did you have lunch alone or with others? Have you been looking at your mobile longer? Did you sit alone?). A debriefing about the study and its goals was provided after submission of the post-lunch survey. Optionally, participants could upload pre-lunch and post-lunch photos of their meals to monitor meal choice and compliance. In the randomized condition, the post-survey also asked whether participants were satisfied with the randomized condition, or if not, which meal choice they would have preferred.

Participants of sub-study 1 were not remunerated due to a very brief study completion time. Substudies 2+3 were remunerated with $9 €$ for participation, with an optional extra $2 €$ per questionnaire (TFEQ, FFQ, NEO-FFI). All data was collected from Jan 2019 until Feb 2020.

\section{Meal categorization}

For analysis meal categorization was done by study personnel based on provided meal category (vegetarian, vegan, meat or fish) and more specific meal description as given in the menu and by information on allergens (keywords: animal-based: poultry, pork, beef, lamb, meat, fish, scampi, seafood, deer, piglet, duck, goose, salami, ham, wiener; plant-based: vegan, vegetarian, meatfree, tofu, soy). Categorization was done manually and in case of ambiguity based on consensus amongst study personnel. All remaining ambiguous meals were assigned missing value (e.g. in case meal description included both animal-based and plant-based keywords, e.g. "Tofuwurst oder Currywurst", "... also available in vegan", "Salatbuffet je $100 \mathrm{~g}$ Auswahl an frischen Salaten, Gemüse-, Fisch-, Geflügel-, Schweine- und Rindfleisch- und vegetarischen und veganen Gerichten").

\section{Missing data and data selection/exclusion}

All data was screened for plausibility, consistency and distribution and curated as appropriate. This included assigning meal category based on available information (meal description, information on allergens, meal photo). In sub-study 3 , non-compliance with the assigned meal 
medRxiv preprint doi: https://doi.org/10.1101/2021.10.24.21265240; this version posted October 26, 2021. The copyright holder for this preprint (which was not certified by peer review) is the author/funder, who has granted medRxiv a license to display the preprint in It is made available under a CC-BY-NC-ND 4.0 International license .

category led to exclusion. Implausible datapoints were treated as missing. Missing data was treated as missings (linear mixed models), except for meal category, which led to exclusion of the datapoint in all analyses.

Data entry plausibility was monitored with time stamp information and, if available, based on the creation dates of the uploaded meal photos. In sensitivity analyses, data was excluded according to the following criteria: post-meal entries appeared to be made prior than pre-meal entries; data entry outside of liberal time frame for more than $5 \mathrm{~min}$ and more less $3 \mathrm{~h}$ time lag between preand post-meal (hunger) entries (pre- and post-meal entries outside of 7:45 am and 10:30 pm (cafeteria opening hours (10:45 am to 7:30 pm) $+3 \mathrm{~h}$ data entry time frame); as well as data entry outside of a conservative time frame more than $20 \mathrm{~min}$ and less than $1.5 \mathrm{~h}$ time lag between preand post-meal (hunger) entries; (pre- and post-meal entries outside of 9:15 am and $9 \mathrm{pm}$ (cafeteria opening hours $+1.5 \mathrm{~h}$ data entry time frame)) (note: we corrected timings indicated in the pre-registration). In sub-studies 2 and 3 only, duplicate records of the same participant were checked for consistency and curated accordingly so that each participant would only be counted once.

For detailed information on data curation and power calculations, see SI.

\section{Data analysis}

As pre-registered (https://osf.io/a7yts), statistical analyses comprised linear mixed model comparisons using Imer() in R. We tested the following hypotheses regarding interaction effects:

\section{Primary analysis}

(1) A plant-based (i.e., vegan, vegetarian) meal will lead to better mood, higher satiety and less stress compared to an animal-based meal.

$$
\begin{aligned}
& \text { R1=Imer (mood } \sim \text { timepoint }+ \text { meal }+ \text { timepoint:meal }+(1 \mid \text { subject })+(1 \mid \text { cafeteria })) \\
& \text { Null model =Imer (mood } \sim \text { timepoint }+ \text { meal }+(1 \mid \text { subject })+(1 \mid \text { cafeteria })) \\
& \text { Note: "meal" was defined as vegan or vegetarian }(0) \text { vs. animal-based }(1) .
\end{aligned}
$$

Two more analyses were performed with satiety and stress as dependent variables.

Additionally, we performed simpler models to test for main effects of meal category.

Transformations. Normal distribution of the raw values and residuals was assessed by evaluating visually the uniformity of the maximum and a skewness of $<|1|$. Skewed unimodal distributions were transformed using logarithmic or other transformations to reach normal distributions.

Inference criteria. The alpha level was adjusted to multiple comparisons ( 3 main tests per study sample), so that the significance threshold was set to $p<0.05 / 3=0.0167$, and $p<0.05$ for all other models.

\section{Exploratory analysis}

(2) A voluntary decision to eat a plant-based meal (vegetarian or vegan) compared to an animalbased meal will be more frequently made upon planned decisions. Chi-square test performed for categorical outcome (planned vs. impulsive decision):

chisq.test(meal, decision) 
medRxiv preprint doi: https://doi.org/10.1101/2021.10.24.21265240; this version posted October 26, 2021. The copyright holder for this preprint (which was not certified by peer review) is the author/funder, who has granted medRxiv a license to display the preprint in It is made available under a CC-BY-NC-ND 4.0 International license

(3) Higher fiber content in the meals will mediate higher mood and satiety and lower stress, whereas higher unrefined sugar and fat content will mediate the opposite.

Deviating from the pre-registration, models (and planned mediation analyses) for fiber content could not be performed, as data was not available.

(4) The former potential effects (2) will be masked in participants that followed, and in particular in those that also disliked, a non-voluntary decision of meal category. "decision" will be defined in three levels, as "voluntary vs. non-voluntary-liked vs non-voluntary-disliked":

$$
\begin{aligned}
& \text { R1=Imer }\left(\text { mood } \sim \text { timepoint }+ \text { decision_liking }+ \text { meal }{ }^{*} \text { decision_liking }+ \text { meal }+(1 \mid \text { subject })\right. \\
& +(1 \mid \text { Mensa })) \\
& \text { Null model }=\text { Imer }(\text { mood } \sim \text { timepoint }+ \text { decision_liking }+ \text { meal }+(1 \mid \text { subject })+(1 \mid \text { Mensa }))
\end{aligned}
$$

Two more models accordingly for hunger and stress. We further speculate that energy intake (kcal), fluids, meal ratings, daytime, environment, lifestyle and dietary habits, social interaction, personality traits and other factors such as age and sex may modulate the above effects.

Therefore, we included those variables additionally as factors into the above described models.

Inference criteria. The alpha level was set to $p<0.05$ due to the exploratory nature of the analysis if not stated otherwise. 
medRxiv preprint doi: https://doi.org/10.1101/2021.10.24.21265240; this version posted October 26, 2021. The copyright holder for this preprint (which was not certified by peer review) is the author/funder, who has granted medRxiv a license to display the preprint in It is made available under a CC-BY-NC-ND 4.0 International license

\section{Author Contribution}

EM, AV, AVW: study conception and design; EM, LdB, MZ: data collection and data management; EM: data curation; AVW: meal category labeling for the app-study; EM, AVW: data analysis of all sub-studies; EM: data visualization; EM, AVW: first manuscript draft. All authors contributed to and accepted the final manuscript.

\section{Conflict of interest}

Authors had the following dietary adherences at the time of study: omnivorous (LdB, AV), vegetarian (AVW), vegan (EM, MZ).

\section{Acknowledgments}

We would like to thank Maria Paerisch for the administrative advice and support for setting up the three online studies, Lena Weidert for initial data curation of sub-studies two and three and David Villringer for initial data analysis of the app study. Also we thank AIMPULSE Intelligent Systems $\mathrm{GmbH}$, Bremen, Germany and the local Studierendenwerke (student unions) for integrating our study into their services and for providing the data. We also thank all the volunteers who participated in the studies.

\section{Funding}

Funding was provided by the Max Planck Society and a promotion stipend by the German Federal Environmental Foundation (EM). Open Access funding enabled and organized by Projekt DEAL. 
medRxiv preprint doi: https://doi.org/10.1101/2021.10.24.21265240; this version posted October 26, 2021. The copyright holder for this preprint (which was not certified by peer review) is the author/funder, who has granted medRxiv a license to display the preprint in perpetuity.

It is made available under a CC-BY-NC-ND 4.0 International license.

\section{References}

1. Willett W, Rockström J, Loken B, et al (2019) Food in the Anthropocene: the EAT-Lancet Commission on healthy diets from sustainable food systems. Lancet 393:447-492

2. Clark MA, Springmann M, Hill J, Tilman D (2019) Multiple health and environmental impacts of foods. Proc Natl Acad Sci 116:23357-23362

3. Medawar E, Huhn S, Villringer A, Witte AV (2019) The effects of plant-based diets on the body and the brain: A systematic review. Transl Psychiatry 9:

4. Medawar E, Enzenbach C, Roehr S, et al (2020) Less Animal-Based Food, Better Weight Status: Associations of the Restriction of Animal-Based Product Intake with Body-MassIndex, Depressive Symptoms and Personality in the General Population. Nutr 2020, Vol 12, Page 1492 12:1492. https://doi.org/10.3390/NU12051492

5. Reynolds A, Mann J, Cummings J, et al (2019) Carbohydrate quality and human health: a series of systematic reviews and meta-analyses. Lancet. https://doi.org/10.1016/S01406736(18)31809-9

6. O'Keefe SJ (2019) The association between dietary fibre deficiency and high-income lifestyle-associated diseases: Burkitt's hypothesis revisited. Lancet Gastroenterol. Hepatol. 4:984-996

7. Berthoud HR, Münzberg H, Morrison CD (2017) Blaming the Brain for Obesity: Integration of Hedonic and Homeostatic Mechanisms. Gastroenterology 152:1728-1738. https://doi.org/10.1053/j.gastro.2016.12.050

8. Clegg M, Shafat A (2010) Energy and macronutrient composition of breakfast affect gastric emptying of lunch and subsequent food intake, satiety and satiation. Appetite 54:517-523. https://doi.org/10.1016/j.appet.2010.02.005

9. Poppitt SD, McCorMacK D, Buffenstein R (1998) Short-term effects of macronutrient preloads on appetite and energy intake in lean women. Physiol Behav 64:279-285. https://doi.org/10.1016/S0031-9384(98)00061-4

10. Zanchi D, Depoorter A, Egloff L, et al (2017) The impact of gut hormones on the neural circuit of appetite and satiety: A systematic review. Neurosci. Biobehav. Rev. 80:457-475

11. Burger KS, Stice E (2014) Greater striatopallidal adaptive coding during cue-reward learning and food reward habituation predict future weight gain. Neuroimage 99:122-128. https://doi.org/https://doi.org/10.1016/j.neuroimage.2014.05.066

12. Jovanovski E, Mazhar N, Komishon A, et al (2020) Can dietary viscous fiber affect body weight independently of an energy-restrictive diet? A systematic review and metaanalysis of randomized controlled trials. Am J Clin Nutr 111:471-485. https://doi.org/10.1093/ajcn/nqz292

13. Dalile B, Van Oudenhove L, Vervliet B, Verbeke K (2019) The role of short-chain fatty acids in microbiota-gut-brain communication. Nat. Rev. Gastroenterol. Hepatol. 16:461478

14. Clark MJ, Slavin JL (2013) The effect of fiber on satiety and food intake: A systematic 

medRxiv preprint doi: https://doi.org/10.1101/2021.10.24.21265240; this version posted October $26,2021$. The copyright holder for this
preprint (which was not certified by peer review) is the author/funder, who has granted medRxiv a license to display the preprint in

It is made available under a CC-BY-NC-ND 4.0 International license.

review. J Am Coll Nutr 32:200-211. https://doi.org/10.1080/07315724.2013.791194

15. Muth AK, Park SQ (2021) The impact of dietary macronutrient intake on cognitive function and the brain. Clin. Nutr. 40:3999-4010

16. Cani PD, Van Hul M, Lefort C, et al (2019) Microbial regulation of organismal energy homeostasis. Nat. Metab. 1:34-46

17. Boswell RG, Sun W, Suzuki S, Kober H (2018) Training in cognitive strategies reduces eating and improves food choice. Proc Natl Acad Sci U S A 115:E11238-E11247. https://doi.org/10.1073/pnas.1717092115

18. Ocklenburg S, Borawski J (2021) Vegetarian diet and depression scores: A metaanalysis. J Affect Disord 294:813-815. https://doi.org/10.1016/j.jad.2021.07.098

19. Lassale C, Batty GD, Baghdadli A, et al (2019) Healthy dietary indices and risk of depressive outcomes: a systematic review and meta-analysis of observational studies. Mol. Psychiatry 24:965-986

20. Taylor AM, Holscher HD (2020) A review of dietary and microbial connections to depression, anxiety, and stress. Nutr. Neurosci. 23:237-250

21. Swann OG, Kilpatrick M, Breslin M, Oddy WH (2020) Dietary fiber and its associations with depression and inflammation. Nutr. Rev. 78:394-411

22. Firth J, Firth J, Gangwisch JE, et al (2020) Food and mood: How do diet and nutrition affect mental wellbeing? BMJ 369:. https://doi.org/10.1136/bmj.m2382

23. Broers VJ V., De Breucker C, Van den Broucke S, Luminet O (2017) A systematic review and meta-analysis of the effectiveness of nudging to increase fruit and vegetable choice. Eur J Public Health 27:912-920. https://doi.org/10.1093/eurpub/ckx085

24. Garnett EE, Balmford A, Sandbrook C, et al (2019) Impact of increasing vegetarian availability on meal selection and sales in cafeterias. Proc Natl Acad Sci 116:2092320929

25. Papies EK, Johannes N, Daneva T, et al (2020) Using consumption and reward simulations to increase the appeal of plant-based foods. Appetite 155:104812. https://doi.org/10.1016/j.appet.2020.104812

26. Nielsen L V., Kristensen MD, Klingenberg L, et al (2018) Protein from meat or vegetable sources in meals matched for fiber content has similar effects on subjective appetite sensations and energy intake-A randomized acute cross-over meal test study. Nutrients 10:. https://doi.org/10.3390/nu10010096

27. Griffith C, Piacquadio K, Braden M, Leidy H (2021) Effects of Protein Source and Quantity on Appetite Control, Satiety and Subsequent Food Intake in Healthy Adults. Curr Dev Nutr 5:409-409. https://doi.org/10.1093/cdn/nzab038_021

28. Klementova M, Thieme L, Haluzik M, et al (2019) A plant-based meal increases gastrointestinal hormones and satiety more than an energy-and macronutrient-matched processed-meat meal in $\mathrm{t} 2 \mathrm{~d}$, obese, and healthy men: A three-group randomized crossover study. Nutrients 11:. https://doi.org/10.3390/nu11010157 

medRxiv preprint doi: https://doi.org/10.1101/2021.10.24.21265240; this version posted October $26,2021$. The copyright holder for this
preprint (which was not certified by peer review) is the author/funder, who has granted medRxiv a license to display the preprint in It is made available under a CC-BY-NC-ND 4.0 International license .

29. Koch F, Heuer T, Krems C, Claupein E (2019) Meat consumers and non-meat consumers in Germany: A characterisation based on results of the German National Nutrition Survey II. J Nutr Sci 8:1-13. https://doi.org/10.1017/jns.2019.17

30. El-Salhy M, Ystad SO, Mazzawi T, Gundersen D (2017) Dietary fiber in irritable bowel syndrome (Review). Int. J. Mol. Med. 40:607-613

31. Clark MJ, Slavin JL (2013) The effect of fiber on satiety and food intake: A systematic review. J Am Coll Nutr 32:200-211. https://doi.org/10.1080/07315724.2013.791194

32. David LA, Maurice CF, Carmody RN, et al (2014) Diet rapidly and reproducibly alters the human gut microbiome. Nature 505:559-563. https://doi.org/10.1038/nature12820

33. Michel F, Knaapila A, Hartmann C, Siegrist M (2021) A multi-national comparison of meat eaters' attitudes and expectations for burgers containing beef, pea or algae protein. Food Qual Prefer 91:104195. https://doi.org/10.1016/j.foodqual.2021.104195

34. Strassner C (2019) Food, nutrition and health in Germany. In: Nutritional and Health Aspects of Food in Western Europe. Elsevier, pp 133-158

35. Biermann G, Rau H (2020) The meaning of meat: (Un)sustainable eating practices at home and out of home. Appetite 153:104730.

https://doi.org/10.1016/j.appet.2020.104730

36. Dagevos H (2021) Finding flexitarians: Current studies on meat eaters and meat reducers. Trends Food Sci. Technol. 114:530-539

37. Vadiveloo M, Morwitz V, Chandon P (2013) The interplay of health claims and taste importance on food consumption and self-reported satiety. Appetite 71:349-356. https://doi.org/10.1016/j.appet.2013.09.005

38. Yin W, Hewson L, Linforth R, et al (2017) Effects of aroma and taste, independently or in combination, on appetite sensation and subsequent food intake. Appetite 114:265-274. https://doi.org/10.1016/j.appet.2017.04.005

39. DiFeliceantonio AG, Coppin G, Rigoux L, et al (2018) Supra-Additive Effects of Combining Fat and Carbohydrate on Food Reward. Cell Metab 28:33-44.e3. https://doi.org/10.1016/j.cmet.2018.05.018

40. Weltens $N$, Zhao D, Van Oudenhove $L$ (2014) Where is the comfort in comfort foods? Mechanisms linking fat signaling, reward, and emotion. Neurogastroenterol. Motil. 26:303-315

41. Singh M (2014) Mood, food and obesity. Front Psychol 5:1-35. https://doi.org/10.3389/fpsyg.2014.00925

42. Löffler A, Luck T, Then FS, et al (2015) Age- and gender-specific norms for the German version of the Three-Factor Eating-Questionnaire (TFEQ). Appetite 91:241-247. https://doi.org/10.1016/j.appet.2015.04.044

43. Hilbert A, de Zwaan M, Braehler E (2012) How Frequent Are Eating Disturbances in the Population? Norms of the Eating Disorder Examination-Questionnaire. PLoS One 7:e29125. https://doi.org/10.1371/journal.pone.0029125 
medRxiv preprint doi: https://doi.org/10.1101/2021.10.24.21265240; this version posted October 26, 2021. The copyright holder for this preprint (which was not certified by peer review) is the author/funder, who has granted medRxiv a license to display the preprint in perpetuity.

It is made available under a CC-BY-NC-ND 4.0 International license .

44. Rosenfeld DL (2020) Gender differences in vegetarian identity: How men and women construe meatless dieting. Food Qual Prefer 81:103859.

https://doi.org/10.1016/j.foodqual.2019.103859

45. Grzymisławska M, Puch EA, Zawada A, Grzymisławski M (2020) Do nutritional behaviors depend on biological sex and cultural gender? Adv Clin Exp Med Off organ Wroclaw Med Univ 29:165-172

46. Wardle J, Haase AM, Steptoe A, et al (2004) Gender differences in food choice: The contribution of health beliefs and dieting. Ann Behav Med 27:107-116.

https://doi.org/10.1207/s15324796abm2702_5

47. Grammer AC, Vázquez MM, Fitzsimmons-Craft EE, et al (2021) Characterizing eating disorder diagnosis and related outcomes by sexual orientation and gender identity in a national sample of college students. Eat Behav 42:101528.

https://doi.org/10.1016/j.eatbeh.2021.101528

48. Janssen M, Busch C, Rödiger M, Hamm U (2016) Motives of consumers following a vegan diet and their attitudes towards animal agriculture. Appetite 105:643-651. https://doi.org/10.1016/j.appet.2016.06.039

49. Brytek-Matera A (2021) Vegetarian diet and orthorexia nervosa: a review of the literature. Eat. Weight Disord. 26:1-11

50. Grootswagers T (2020) A primer on running human behavioural experiments online. Behav Res Methods 52:2283-2286. https://doi.org/10.3758/s13428-020-01395-3

51. Deehan EC, Walter J (2016) The Fiber Gap and the Disappearing Gut Microbiome: Implications for Human Nutrition. Trends Endocrinol. Metab. 27:239-242

52. Rosenfeld DL, Tomiyama AJ (2020) Taste and health concerns trump anticipated stigma as barriers to vegetarianism. Appetite 144:104469.

https://doi.org/10.1016/j.appet.2019.104469

53. Clark MA, Springmann M, Hill J, Tilman D (2019) Multiple health and environmental impacts of foods. Proc Natl Acad Sci U S A 116:23357-23362.

https://doi.org/10.1073/pnas.1906908116

54. Haftenberger M, Heuer T, Heidemann C, et al (2010) Relative validation of a food frequency questionnaire for national health and nutrition monitoring

55. Costa PT, McCrae RR (1989) NEO PI/FFI manual supplement for use with the NEO Personality Inventory and the NEO Five-Factor Inventory. Psychological Assessment Resources 
medRxiv preprint doi: https://doi.org/10.1101/2021.10.24.21265240; this version posted October 26, 2021. The copyright holder for this preprint (which was not certified by peer review) is the author/funder, who has granted medRxiv a license to display the preprint in

It is made available under a CC-BY-NC-ND 4.0 International license .

\section{Figure Legends}

Figure 1: Study design: Adults ( $\mathrm{m}, \mathrm{f}, \mathrm{d}$ ) consuming a single meal in university cafeterias rated hunger and mood using Likert scales before and after that meal with smartphones or mobile devices, in an app study ( $\mathrm{n}_{1}=16,135,5$-point scales, top row) or in a more detailed web-based survey (omnivorous diet habits only, 10-point scales, $n_{2}=173$ : free choice, $n_{3}=71$ : randomized choice; middle row). Photos (bottom row) show exemplary pre- and post-meal plates for both meal categories. Photos are screenshots taken from iMensa app directly and meal photos provided by study participants (available at https://osf.io/mqc5d/).

Figure 2: Demographic factors and study sample descriptives of sub-studies 1, 2 and 3. Image rights: Freepik (smartphone, diet, water, network, eat, clock, broccoli, tofu, peas, chickpea, soy, vegan, sausage, chop, food), Smashicons (brain), DinosoftLabs (chicken leg), surgan (seafood).

Figure 3: Mean ratings of pre- and post-meal category for hunger, mood/contentment and stress. Appstudy ratings depicted in A) hunger $B$ ) mood, C) sub-study 2 with free meal choice ( $n=173)$ and $B$ ) substudy 3 with randomized meal allocation $(n=78)$. Median depicted as line, mean as dot, outliers (according to interquartile rule) as triangles.

Figure 4: Nutrient composition between meal categories in a subsample of the app-study $\left(n_{\max }=1262\right.$, data from app study). Macronutrient information per portion size for A) calories in kcal B) fat in grams $C$ ) saturated fats in grams $D$ ) carbohydrates in grams $E$ ) sugar in grams and F) protein in grams. Median depicted as line, outliers (according to interquartile rule) as dots.

Figure 5: Mean ratings of pre- and post-meal for hunger and mood by white flour vs. whole-grain flour bolognese meals (app-study only $(n=442)$ depicted in $A$ ) hunger $B$ ) mood. Median depicted as line, mean as dot, outliers (according to interquartile rule) as triangles.

Figure 6: Effects of taste ratings on hunger and mood by star rating provided (app study only). A) Hunger ratings by taste rating from 1 to 5 stars B) Mood ratings by taste rating from 1 to 5 stars. Median depicted as line, mean as dot, outliers (according to interquartile rule) as small dots.

Figure 7: Correlation of post-pre changes between hunger and mood levels (app study only). Spearman's correlation and $99.9 \% \mathrm{Cl}$.

Figure 8: Effects of gender on hunger and mood (app study only, $n_{\text {male }}=8291, n_{\text {female }}=7418, n_{\text {diverse }}=$ 279). Median depicted as line, mean as dot, outliers (according to interquartile rule) as triangles.

Figure 9: Post-randomization contentment and post-meal contentment and reasons for the latter (substudy $2, n=71)$. A) Pre-meal allocation contentment rating (1-10 Likert scale) by meal category. Mean depicted as dot. B) Post-meal allocation contentment in categorical answers depicted as frequency by meal category. C) Reasons for post-meal contentment in categorical answers depicted as frequency by meal category. D) Reasons for post-meal discontentment in categorical answers depicted as frequency by meal category.

Table 1: Demographic information across studies.

Table 2: Ratings for hunger, mood, stress across all studies. Mean \pm SD. Significant models of interest compared to null model in bold (LMM comparison $p<0.001)$.

SI Figure 1: Flowchart with sample size for all studies for all sub-analyses.

SI Figure 2: Frequency of meal category choice plotted by federal states across Germany (colour coding by local student union) for the app study. More detailed data available upon request. A: Berlin B: Saxony C: North-Rhine Westphalia D: Thuringa E: Bavaria F: Baden Württemberg G: Sachsen Anhalt H: Bremen I: Hamburg J: Hesse K: Saarland L: Brandenburg M: Mecklenburg Western Pomerania N: Lower Saxony O: Rhineland Palatinate P: Schleswig Holstein. 
medRxiv preprint doi: https://doi.org/10.1101/2021.10.24.21265240; this version posted October 26, 2021. The copyright holder for this preprint (which was not certified by peer review) is the author/funder, who has granted medRxiv a license to display the preprint in It is made available under a CC-BY-NC-ND 4.0 International license

SI Figure 3: Participation numbers plotted by city and by meal category in time (studies $2+3$ ).

SI Figure 4: Eating behaviour of individuals in sub-studies 2+3 for A) nutrient intake based on 1-week FFQ data and B) eating traits according to Three-Factor Eating Questionnaires subscales.

SI Figure 5: Correlation of post-pre changes between hunger, mood and stress levels for sub-studies 2 and 3. Spearman's correlation and $99.9 \% \mathrm{Cl}$.

SI Figure 6: Frequency of taste ratings of meals per meal category per gender (app study only).

SI Figure 7: Frequency of taste ratings of meals per meal category per dietary adherence group (app study only).

SI Table 1: Macronutrient composition differences between meal categories $\left(\mathrm{n}_{\max }=1262\right.$, data from app study).

SI Table 2: Interaction effects of taste ratings on hunger and mood post-meal (app study only).

SI Table 3: Interaction effects of meal category on hunger and mood for subgroups by gender (app study only).

SI Table 4: Interaction effects of meal category on hunger and mood for subgroups according to dietary adherence (app study only).

\section{Supporting Information}

\section{Power calculation}


medRxiv preprint doi: https://doi.org/10.1101/2021.10.24.21265240; this version posted October 26, 2021. The copyright holder for this preprint (which was not certified by peer review) is the author/funder, who has granted medRxiv a license to display the preprint in It is made available under a CC-BY-NC-ND 4.0 International license .

The ethics proposal submitted to the institutional ethics board of the Medical Faculty of the University of Leipzig, Germany, (228/18-ek) included power calculations for all three studies.

For the app study, power calculation was based on a study by Koenig et al. (2018), resulting in a target sample size of 126 , assuming the observed effect size. This study observed an effect in the eating decision behavior depending on the adaptation of a behavior model $\left(\eta^{2}=0.03\right.$, corresponds to an effect size $d=0.35$ (https://www.psychometrica.de/effect size.html)). However, it is difficult to estimate the effect size of our study, since many influencing factors cannot be determined within the framework of an app study. The analyses therefore remain largely explorative. Due to the large number of users of the app (currently: approx. 300,000 users, approx. 30,000 meal evaluations per month), groups of the same size can be pseudorandomized for better statistical evaluation. If $10 \%$ of active users are included in the study, 3,000 meal-wellbeing associations per month can be collected. Therefore, we assume to achieve a sufficient sample size to determine a possible effect.

Sub-studies $2+3$ were based on the effect size of the study by Reed and Ones $(2006)(d=0.47)$, which examined the effect of a one-time sporting activity on mood values (studies that examined the influence of a one-time meal on mood are missing so far). Study 2 has the following special features: a) a smaller effect was assumed $(d=0.30)$ than in study 3 , because of the absence of randomization, b) a dropout rate of $20 \%$ was added to the calculated sample size, c) a $1: 3$ distribution from plant-based dishes to meat dishes was assumed. Thus, based on the sample size of the power analysis of 172 test people, a sample size of 210 subjects suggested to observe the desired effect. For sub-study 3, power calculation is analogous to sub-study 2, but defers in the following points: a) effect size of the study by Reed and Ones (2006) was assumed ( $d=0.47)$, which investigated the effect of a one-time physical activity intervention on mood. Assuming a dropout rate of $20 \%$, we assume that a targeted sample size from 85 (up to 6,300 portions per day in one of the locations of the Leipzig student union, source: Mensa on Park, see https://www.liz.de/detector/movement-detector/2015/04/three-headed-team-takes-over-leading-of-the-

mensa-am-park-des-studentenwerkes-leipzig-84262).

\section{Stopping rule}

When estimated sample sizes according to power calculation were met, data collection was stopped.

\section{Data curation}

For detailed information on data curation for sub-studies 2+3, see https://osf.io/ucq6r/.

\section{Meal choice descriptives}

Meals chosen by category were between $47-61 \%$ animal-based; with $55 \%$ animal-based in the app-study (8848 animal-based, 7287 plant-based) 61\% animal-based in sub-study two (105 animal-based, 68 plant-based) and $47 \%$ animal-based in sub-study three (37 animal-based, 41 plant-based).

\section{Meal photos}

Meal photos before and after meal intake were optionally uploaded by the participants in substudies two and three. Photos were used to check accordance with self-reported meal description, as well as time-stamp of the photos and compliance with study design for randomized choice in sub-study 3. All photos are stored at https://osf.io/mqc5d/ and can be used for further nutrient analysis or other purposes upon request to the corresponding author. 
medRxiv preprint doi: https://doi.org/10.1101/2021.10.24.21265240; this version posted October 26, 2021. The copyright holder for this preprint (which was not certified by peer review) is the author/funder, who has granted medRxiv a license to display the preprint in perpetuity.

It is made available under a CC-BY-NC-ND 4.0 International license

\section{Sample descriptives}

In the app-based study, planned meal decisions were more frequently made for plant-based $(72 \%)$ compared to animal-based meals $(62 \%)$. Eating alone was more frequent $(23 \%)$, when having a plant-based compared to animal-based meal $(21 \%)$. Finishing the chosen meal was slightly more frequently reported by individuals choosing an animal-based (87\%) compared to plant-based meal (86\%). Drinking volume before the meal, smartphone use and sleep was not different across meal categories. In sub-studies 2 and 3, neither body mass index (BMI) nor income nor general well-being differed across meal categories. Additionally, in sub-study 2 omnivores choosing a plant-based meal were characterized by similar habitual nutrient intake compared to omnivores choosing animal-based meals, except for significantly higher fiber intake (22 \pm 11 vs. $18 \pm 9 \mathrm{~g}$ fiber / day) and significantly higher scores for cognitive restraint and hunger in the TFEQ subscales, Table 1). No differences in personality traits or general well-being were found. Respective differences were not significant for the randomized allocation samples in substudy 3 . 
medRxiv preprint doi: https://doi.org/10.1101/2021.10.24.21265240; this version posted October 26, 2021. The copyright holder for this preprint (which was not certified by peer review) is the author/funder, who has granted medRxiv a license to display the preprint in It is made available under a CC-BY-NC-ND 4.0 International license.
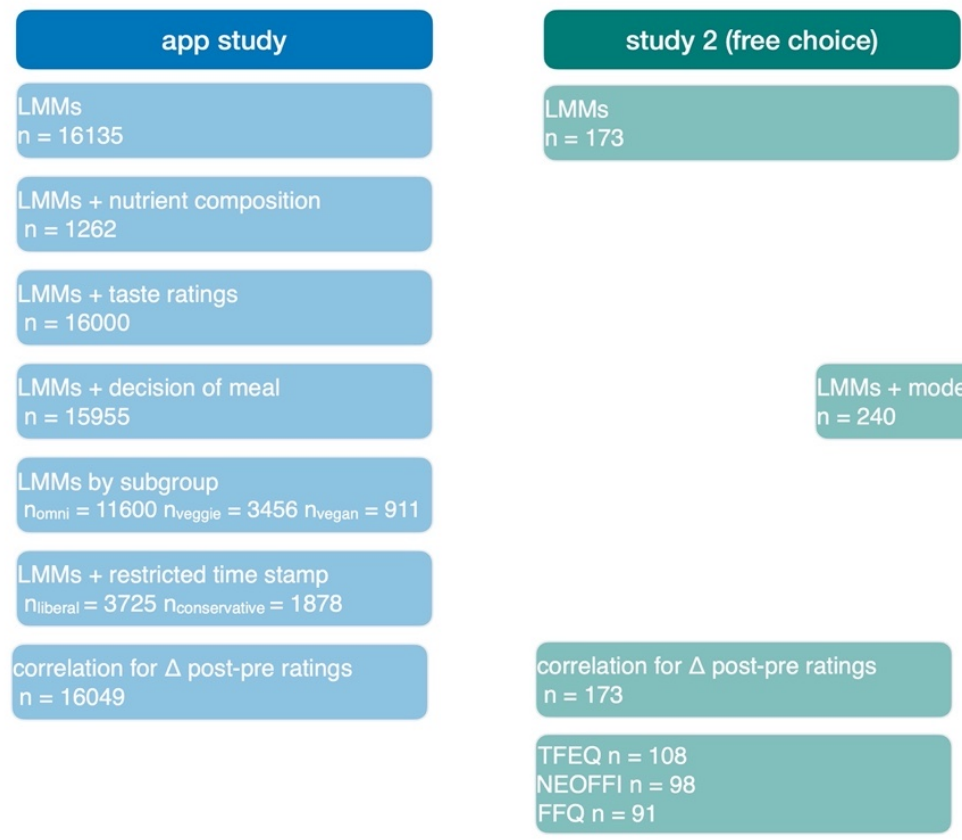

\section{study 3 (randomized choice)}

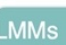

$n=71$

LMMs + pre-contentment $\mathrm{n}=71$

MMs + post-contentment $\mathrm{l}=71$

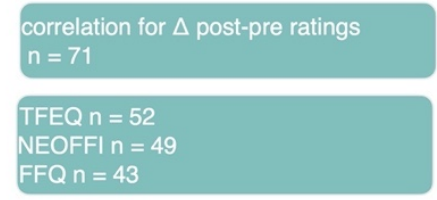

SI Figure 1: Flowchart with sample size for all studies for all sub-analyses. 
medRxiv preprint doi: https://doi.org/10.1101/2021.10.24.21265240; this version posted October 26, 2021. The copyright holder for this preprint (which was not certified by peer review) is the author/funder, who has granted medRxiv a license to display the preprint in It is made available under a CC-BY-NC-ND 4.0 International license .
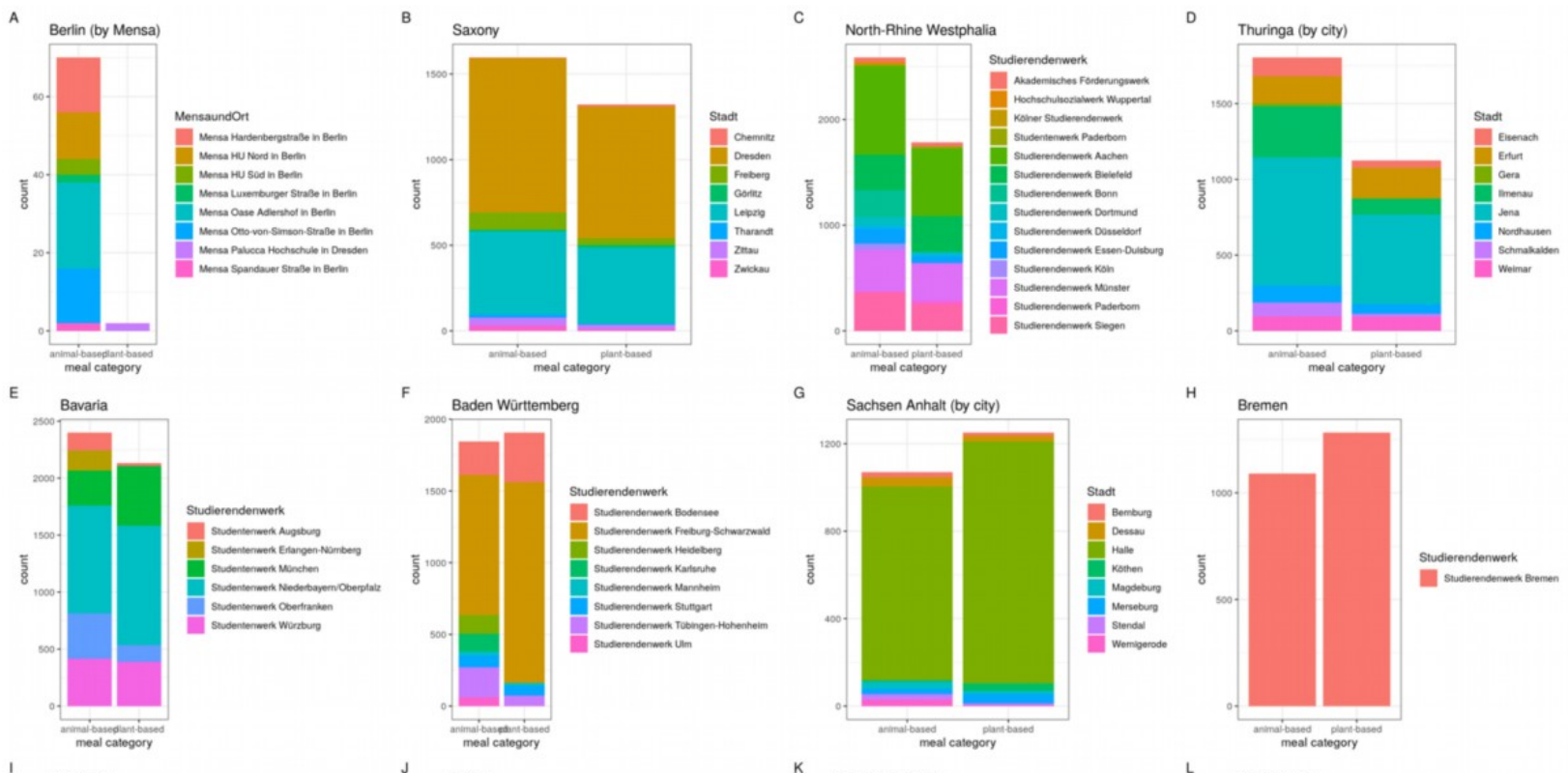

Bremen
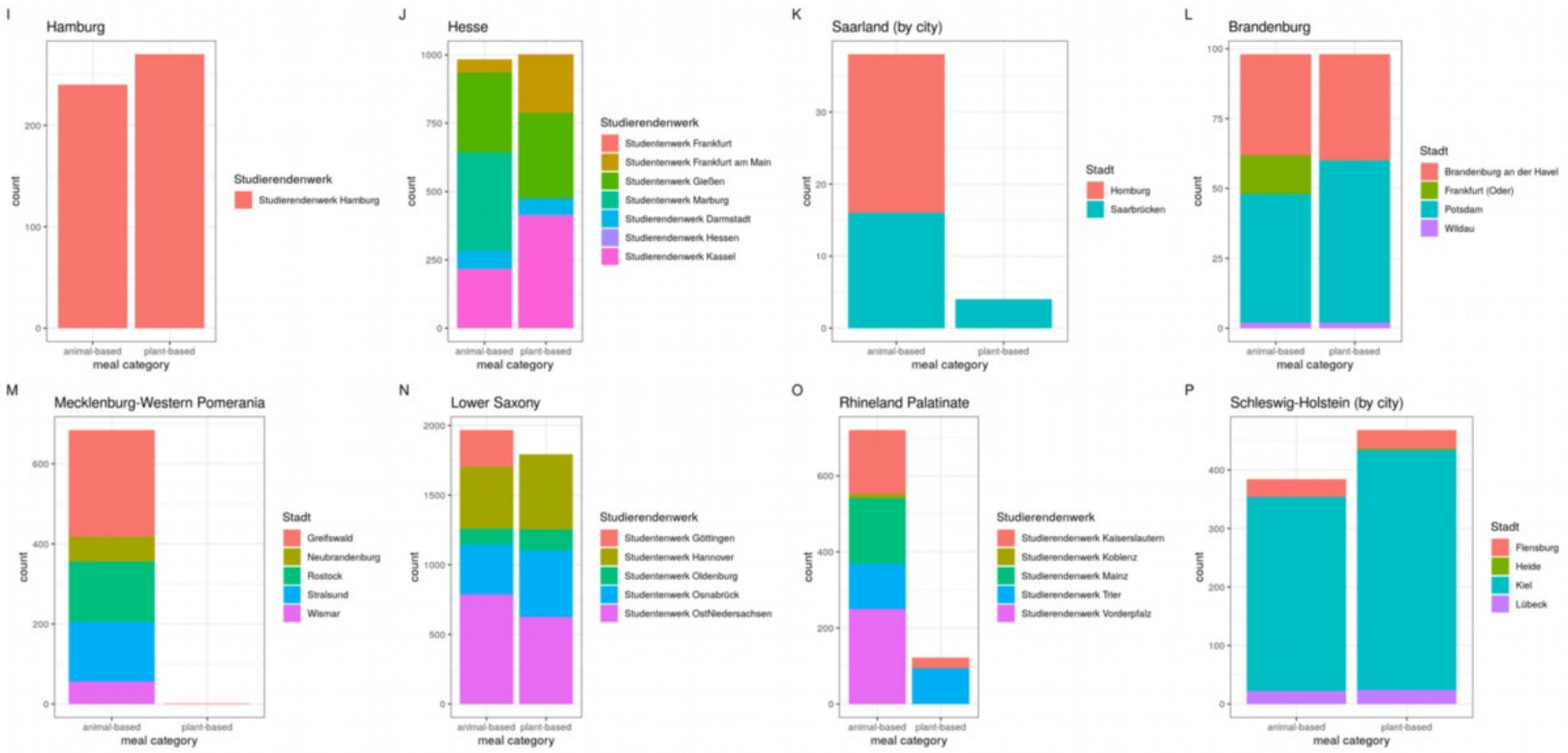

SI Figure 2: Frequency of meal category choice plotted by federal states across Germany (colour coding by local student union) for the app study. More detailed data available upon request. A: Berlin B: Saxony C: North-Rhine Westphalia D: Thuringa E: Bavaria F: Baden Württemberg G: Sachsen Anhalt H: Bremen I: Hamburg J: Hesse K: Saarland L: Brandenburg M: Mecklenburg Western Pomerania N: Lower Saxony O: Rhineland Palatinate P: Schleswig Holstein. 
medRxiv preprint doi: https://doi.org/10.1101/2021.10.24.21265240; this version posted October 26, 2021. The copyright holder for this preprint (which was not certified by peer review) is the author/funder, who has granted medRxiv a license to display the preprint in perpetuity.

It is made available under a CC-BY-NC-ND 4.0 International license
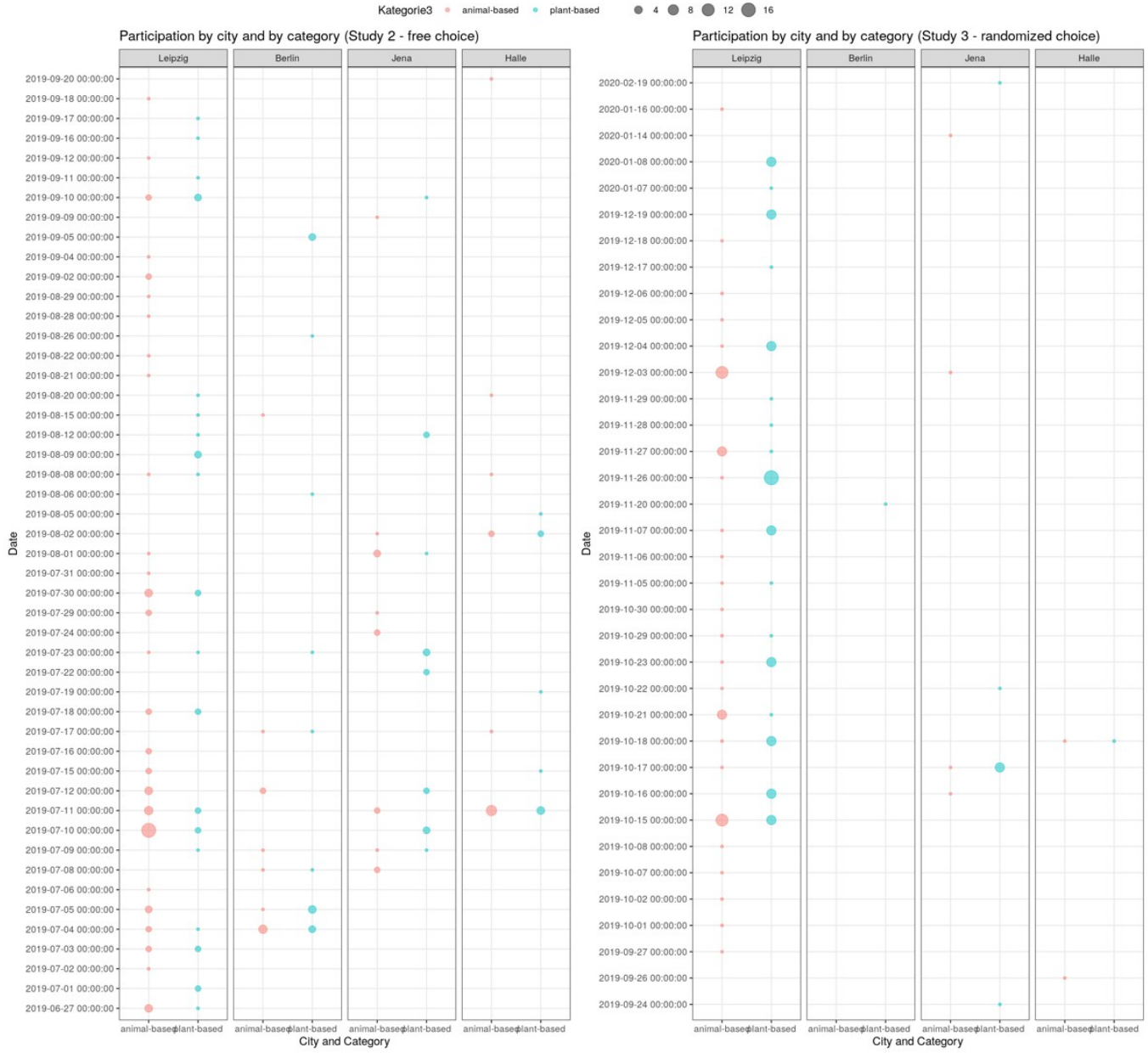

SI Figure 3: Participation numbers plotted by city and by meal category in time (studies $2+3$ ). 
medRxiv preprint doi: https://doi.org/10.1101/2021.10.24.21265240; this version posted October 26, 2021. The copyright holder for this preprint (which was not certified by peer review) is the author/funder, who has granted medRxiv a license to display the preprint in It is made available under a CC-BY-NC-ND 4.0 International license
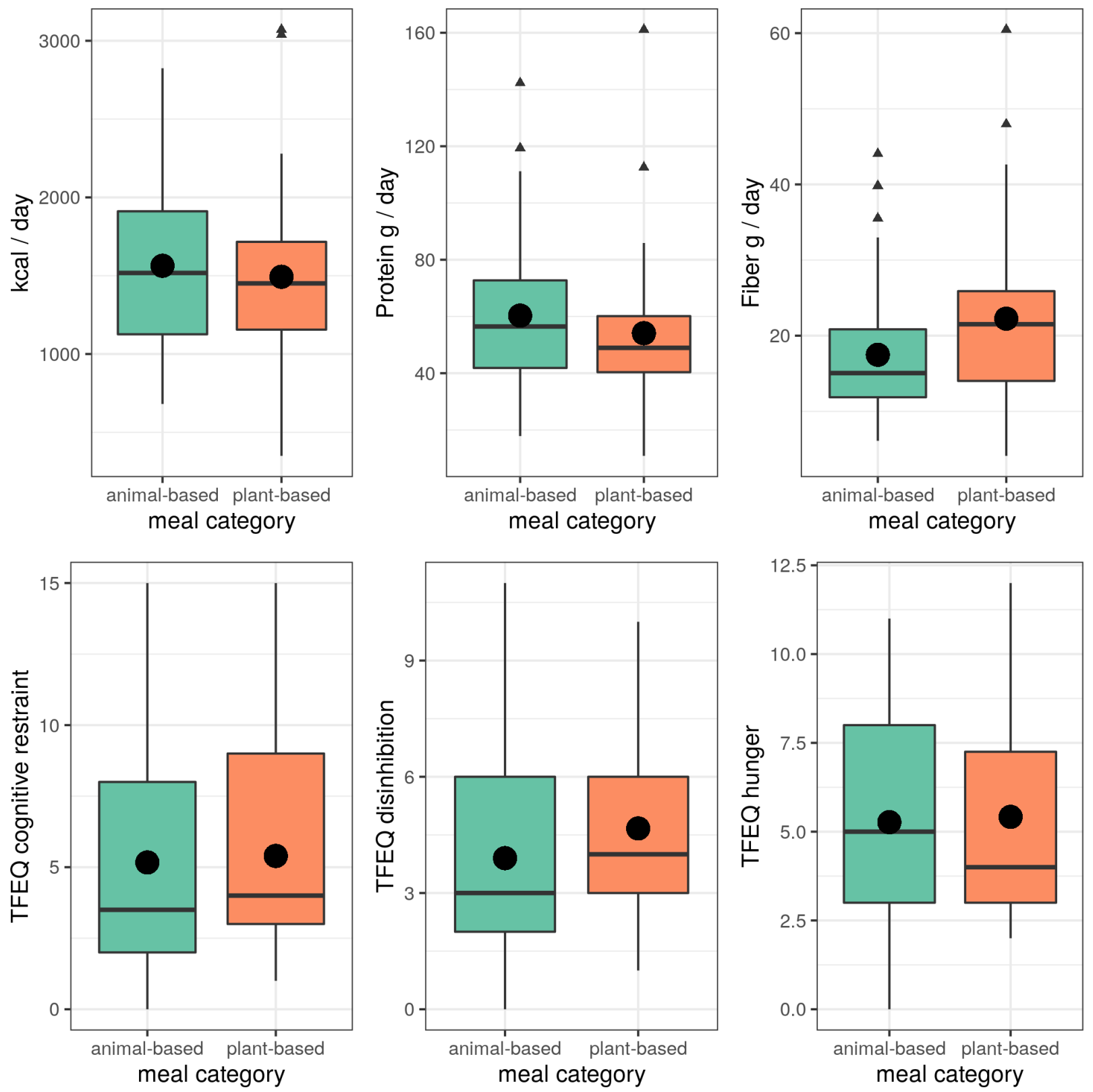

SI Figure 4: Eating behaviour of individuals in sub-studies 2+3 for A) nutrient intake based on 1-week FFQ data and B) eating traits according to Three-Factor Eating Questionnaires subscales. 
medRxiv preprint doi: https://doi.org/10.1101/2021.10.24.21265240; this version posted October 26, 2021. The copyright holder for this preprint (which was not certified by peer review) is the author/funder, who has granted medRxiv a license to display the preprint in perpetuity.

It is made available under a CC-BY-NC-ND 4.0 International license
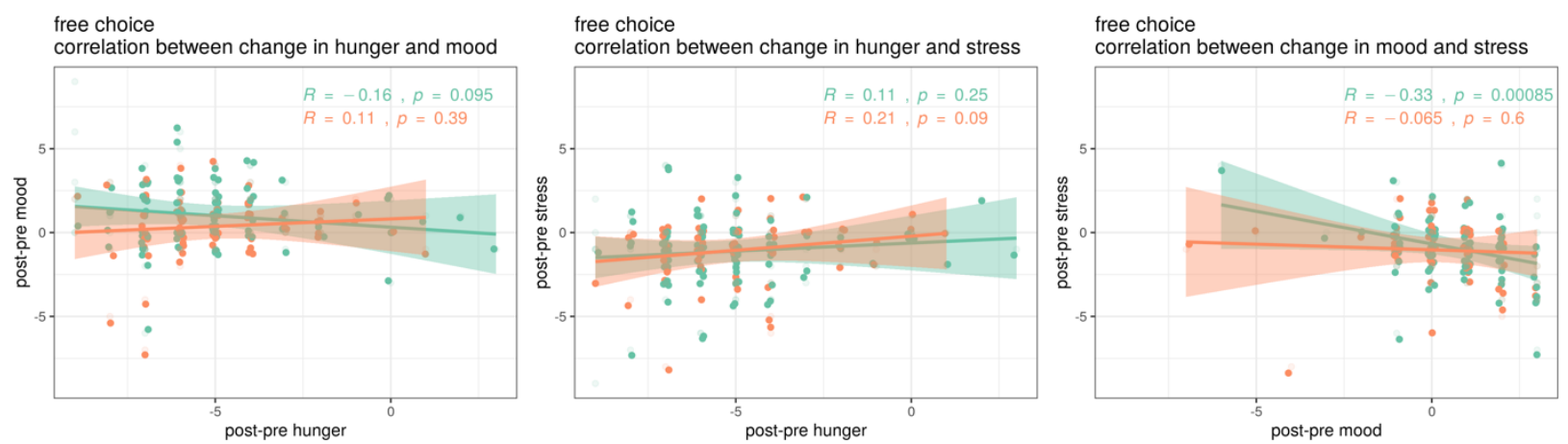

randomized allocation

correlation between change in hunger and mood

randomized allocation

correlation between change in hunger and stress
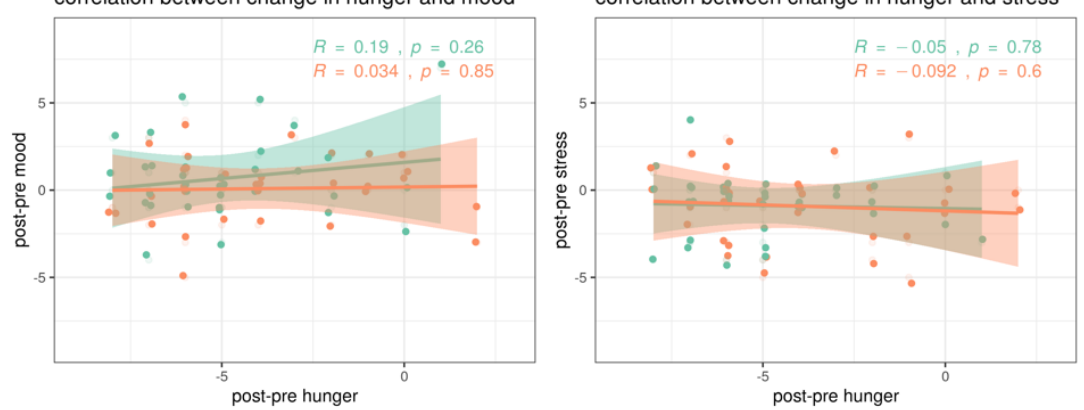

randomized allocation

correlation between change in mood and stress

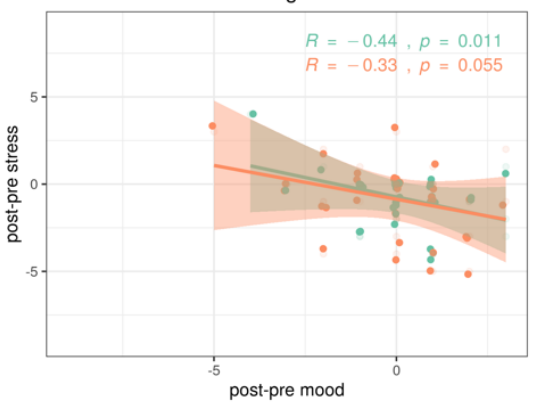

SI Figure 5: Correlation of post-pre changes between hunger, mood and stress levels for sub-studies 2 and 3. Spearman's correlation and $99.9 \% \mathrm{Cl}$. 
medRxiv preprint doi: https://doi.org/10.1101/2021.10.24.21265240; this version posted October 26, 2021. The copyright holder for this preprint (which was not certified by peer review) is the author/funder, who has granted medRxiv a license to display the preprint in It is made available under a CC-BY-NC-ND 4.0 International license .

taste ratings by gender
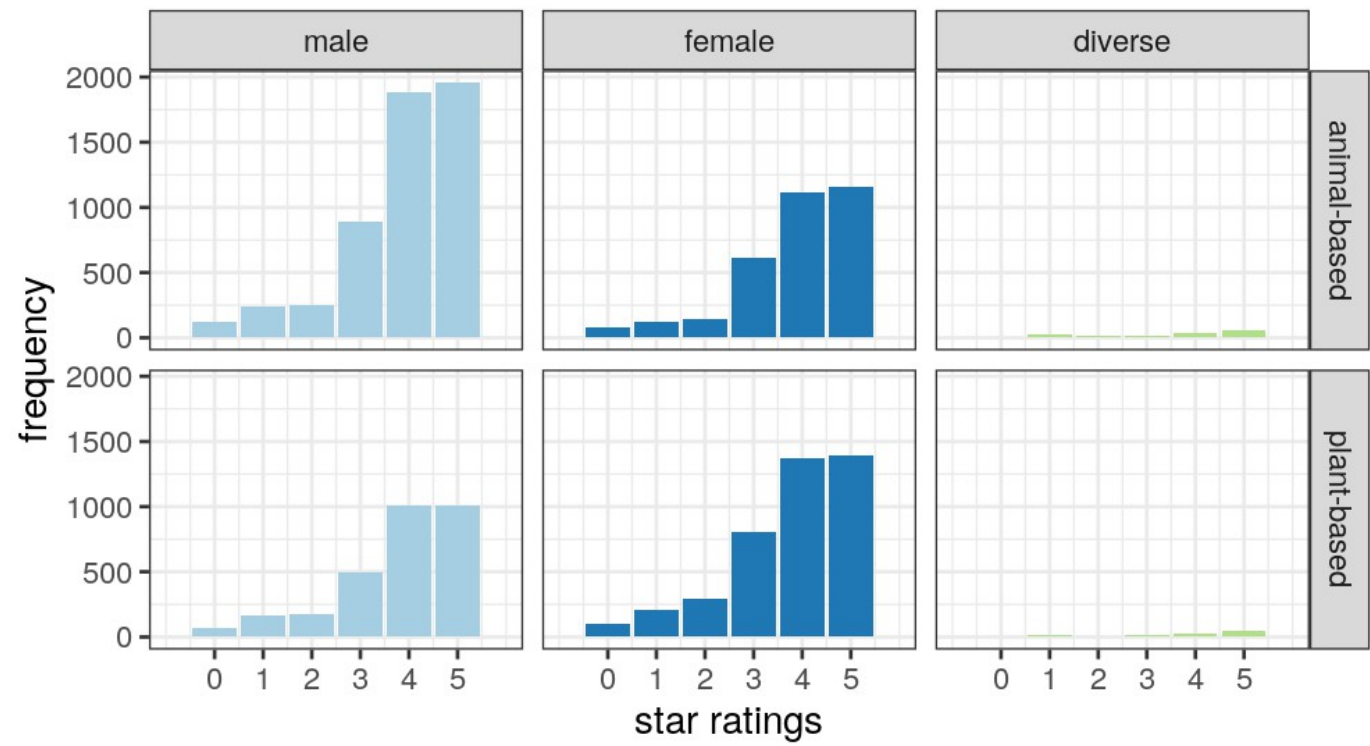

SI Figure 6: Frequency of taste ratings of meals per meal category per gender (app study only).

\section{taste ratings by dietary adherence group}
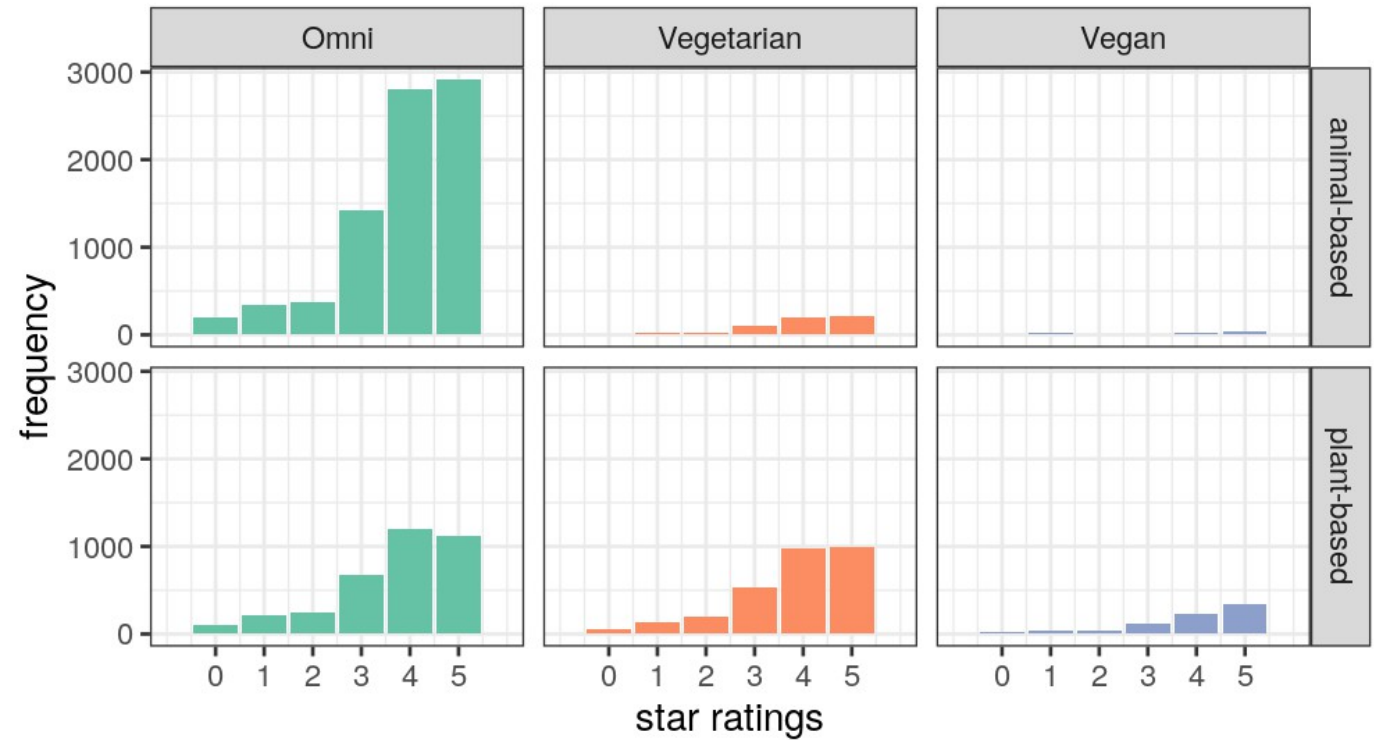

SI Figure 7: Frequency of taste ratings of meals per meal category per dietary adherence group (app study only). 
medRxiv preprint doi: https://doi.org/10.1101/2021.10.24.21265240; this version posted October 26, 2021. The copyright holder for this preprint (which was not certified by peer review) is the author/funder, who has granted medRxiv a license to display the preprint in It is made available under a CC-BY-NC-ND 4.0 International license.

SI Table 1: Macronutrient composition differences between meal categories $\left(n_{\max }=1262\right.$, data from app study).

\begin{tabular}{|l|c|c|c|}
\hline Nutrient & $\begin{array}{c}\text { animal-based meal } \\
\text { mean } \mathbf{~ S D ~}\end{array}$ & $\begin{array}{c}\text { plant-based meal } \\
\text { mean } \mathbf{~ S D ~}\end{array}$ & $\begin{array}{c}\text { Wilcoxon } \\
\text { p-value }\end{array}$ \\
\hline Energy [kcal] & $591 \pm 261$ & $572 \pm 251$ & 0.34 \\
\hline Carbohydrates [g] & $50 \pm 38$ & $71 \pm 38$ & $<0.001$ \\
\hline Sugar [g] & $8 \pm 5$ & $12 \pm 11$ & $\mathbf{0 . 0 0 2}$ \\
\hline Fat [g] & $28 \pm 19$ & $23 \pm 16$ & $<\mathbf{0 . 0 0 1}$ \\
\hline Saturated fats [g] & $8 \pm 7$ & $8 \pm 7$ & 0.86 \\
\hline Protein [g] & $34 \pm 13$ & $18 \pm 10$ & $<\mathbf{0 . 0 0 1}$ \\
\hline Fiber [g] & na & $n a$ & \\
\hline Signifint & & & \\
\hline
\end{tabular}

Significant differences according to Wilcoxon tests between meal categories are marked in bold. 
medRxiv preprint doi: https://doi.org/10.1101/2021.10.24.21265240; this version posted October 26, 2021. The copyright holder for this preprint (which was not certified by peer review) is the author/funder, who has granted medRxiv a license to display the preprint in

It is made available under a CC-BY-NC-ND 4.0 International license

SI Table 2: Interaction effects of taste ratings on hunger and mood post-meal (app study only).

\begin{tabular}{|c|c|c|c|c|}
\hline \multirow[b]{2}{*}{$\begin{array}{l}\text { app-based } \\
\text { (5-point) } \\
n=16000 \text { valid }\end{array}$} & \multicolumn{2}{|l|}{ hunger } & \multicolumn{2}{|l|}{ mood } \\
\hline & animal-based & plant-based & animal-based & plant-based \\
\hline \multicolumn{5}{|l|}{$\begin{array}{l}\text { incl. taste } \\
\text { ratings }\end{array}$} \\
\hline $\begin{array}{l}\text { double interaction } \\
\text { effect } \\
\text { tp*taste }\end{array}$ & \multicolumn{2}{|c|}{ 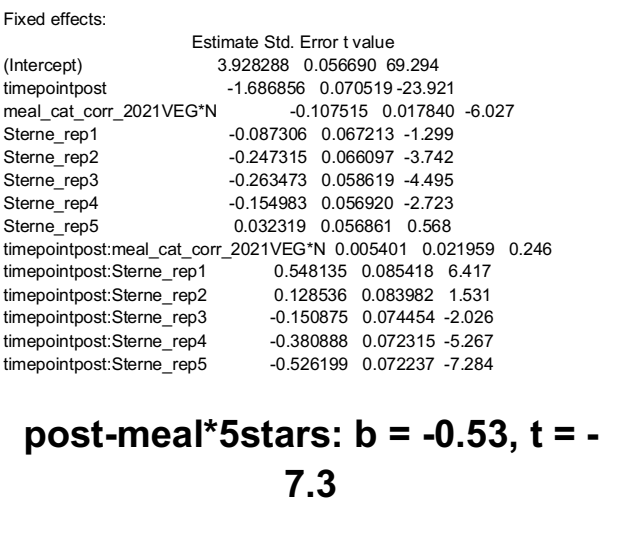 } & \multicolumn{2}{|c|}{ 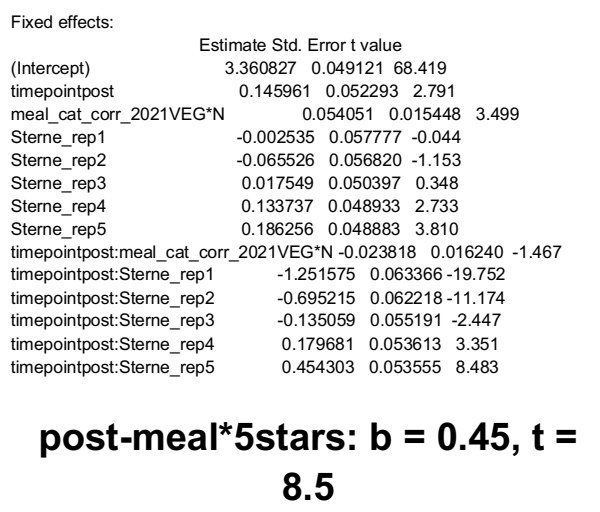 } \\
\hline $\begin{array}{l}\text { triple interaction } \\
\text { effect } \\
\text { tp*meal_cat*taste }\end{array}$ & 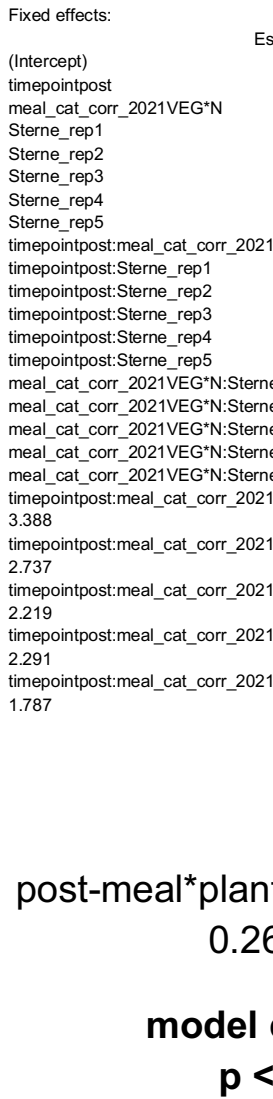 & 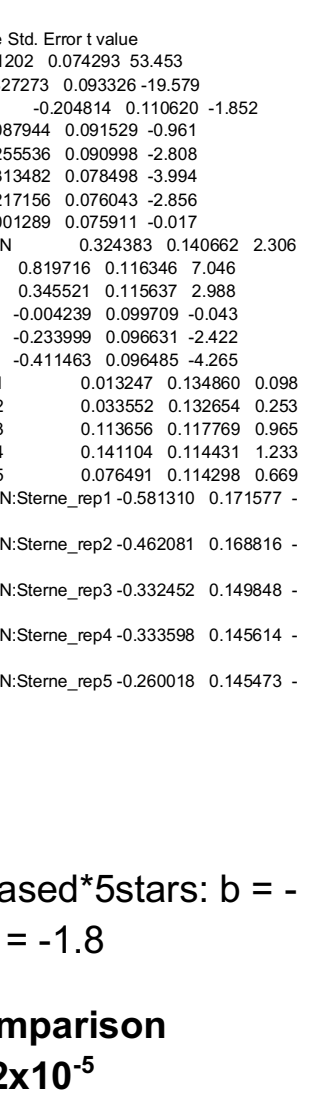 & 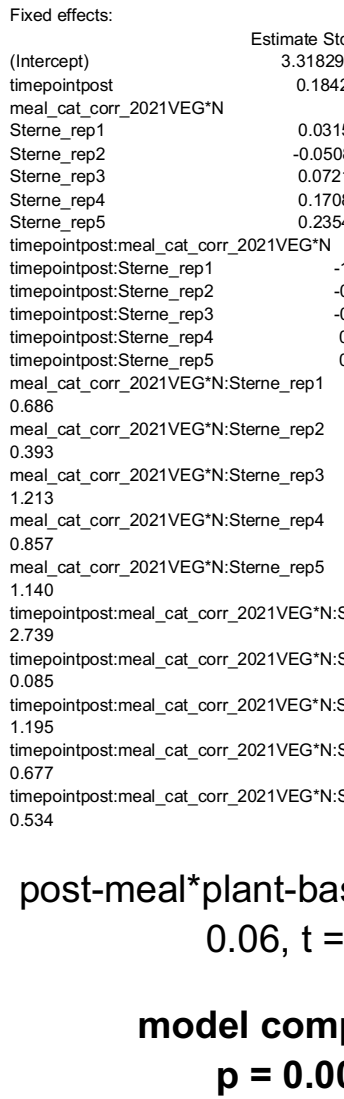 & 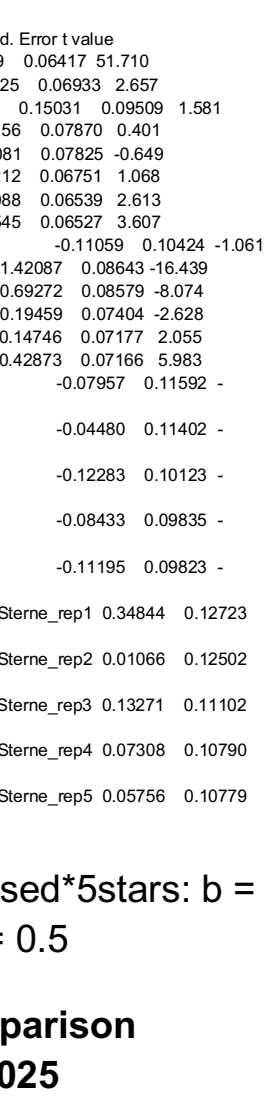 \\
\hline
\end{tabular}

Significant effects between linear mixed models model comparisons are marked in bold. 
medRxiv preprint doi: https://doi.org/10.1101/2021.10.24.21265240; this version posted October 26, 2021. The copyright holder for this preprint (which was not certified by peer review) is the author/funder, who has granted medRxiv a license to display the preprint in It is made available under a CC-BY-NC-ND 4.0 International license.

SI Table 3: Interaction effects of meal category on hunger and mood for subgroups by gender (app study only).

\begin{tabular}{|c|c|c|c|c|}
\hline \multirow{2}{*}{$\begin{array}{l}\text { app-based } \\
\text { (5-point) }\end{array}$} & \multicolumn{2}{|l|}{ hunger } & \multicolumn{2}{|l|}{ mood } \\
\hline & animal-based & plant-based & animal-based & plant-based \\
\hline \multicolumn{5}{|l|}{ male $(n=8291)$} \\
\hline $\begin{array}{l}\text { interaction effect } \\
\text { tp*meal_cat }\end{array}$ & \multicolumn{2}{|c|}{$\begin{array}{c}\text { post-meal }{ }^{*} \text { plant-based: } b=0.07, t= \\
2.2\end{array}$} & \multicolumn{2}{|c|}{$\begin{array}{l}\text { model comparison } \\
\mathbf{p}=\mathbf{0 . 0 0 5}\end{array}$} \\
\hline $\begin{array}{l}\text { main effect } \\
\text { meal_cat }\end{array}$ & \multicolumn{2}{|c|}{$\begin{array}{c}\text { plant-based: } b=-0.01, t=-0.6 \\
\text { model comparison } \\
p<0.53\end{array}$} & \multicolumn{2}{|c|}{$\begin{array}{c}\text { plant-based: } b<0.01, t=0.05 \\
\text { model comparison } \\
p=0.96\end{array}$} \\
\hline \multicolumn{5}{|l|}{ female $(n=7418)$} \\
\hline $\begin{array}{l}\text { interaction effect } \\
\text { tp*meal_cat }\end{array}$ & \multicolumn{2}{|c|}{$\begin{array}{c}\text { post-meal }{ }^{*} \text { plant-based: } b=0.09, t= \\
3.0\end{array}$} & \multicolumn{2}{|c|}{$\begin{array}{l}\text { model comparison } \\
p=4.1 \times 10^{-5}\end{array}$} \\
\hline $\begin{array}{l}\text { main effect } \\
\text { meal_cat }\end{array}$ & \multicolumn{2}{|c|}{$\begin{array}{c}\text { plant-based: } b=-0.07, t=-3.6 \\
\text { model comparison } \\
\mathbf{p}=\mathbf{0 . 0 0 0 4}\end{array}$} & \multicolumn{2}{|c|}{$\begin{array}{c}\text { plant-based: } b=0.02, t=0.9 \\
\text { model comparison } \\
p=0.38\end{array}$} \\
\hline \multicolumn{5}{|l|}{ diverse $(n=279)$} \\
\hline $\begin{array}{l}\text { interaction effect } \\
\text { tp*meal_cat }\end{array}$ & \multicolumn{2}{|c|}{$\begin{array}{c}\text { post-meal*plant-based: } \mathrm{b}=-0.08, \mathrm{t} \\
=-0.4\end{array}$} & \multicolumn{2}{|c|}{$\begin{array}{c}\text { post-meal }{ }^{*} \text { plant-based: } b=0.35, t \\
=1.8 \\
\text { model comparison } \\
p=0.08\end{array}$} \\
\hline $\begin{array}{l}\text { main effect } \\
\text { meal_cat }\end{array}$ & \multicolumn{2}{|c|}{$\begin{array}{c}\text { plant-based: } b=-0.2, t=-1.6 \\
\text { model comparison } \\
p=0.12\end{array}$} & \multicolumn{2}{|c|}{$\begin{array}{l}\text { plant-based: } b=0.01, t=0.04 \\
\text { model comparison } \\
p=0.96\end{array}$} \\
\hline
\end{tabular}

Significant effects between linear mixed models model comparisons are marked in bold. 
medRxiv preprint doi: https://doi.org/10.1101/2021.10.24.21265240; this version posted October 26, 2021. The copyright holder for this preprint (which was not certified by peer review) is the author/funder, who has granted medRxiv a license to display the preprint in It is made available under a CC-BY-NC-ND 4.0 International license .

SI Table 4: Interaction effects of meal category on hunger and mood for subgroups according to dietary adherence (app study only).

\begin{tabular}{|c|c|c|c|c|}
\hline \multirow{2}{*}{$\begin{array}{l}\text { app-based } \\
\text { (5-point) } \\
n=16135 \text { valid }\end{array}$} & \multicolumn{2}{|l|}{ hunger } & \multicolumn{2}{|l|}{ mood } \\
\hline & animal-based & plant-based & animal-based & plant-based \\
\hline \multicolumn{5}{|c|}{ omnivorous only $(n=11600)$} \\
\hline $\begin{array}{l}\text { interaction effect } \\
\text { tp*meal_cat }\end{array}$ & \multicolumn{2}{|c|}{$\begin{array}{c}\text { post-meal }^{*} \text { plant-based: } \mathrm{b}=0.109, \mathrm{t} \\
=3.8\end{array}$} & \multicolumn{2}{|c|}{$\begin{array}{l}\text { model comparison } \\
\mathbf{p}=\mathbf{0 . 0 0 0 0 1 1 4}\end{array}$} \\
\hline $\begin{array}{l}\text { double interaction } \\
\text { effect } \\
\text { tp*taste }\end{array}$ & \multicolumn{2}{|c|}{$\begin{array}{c}\text { post-meal }{ }^{*} 5 \text { stars: } \mathrm{b}=-0.38, \mathrm{t}=-4.5 \\
\text { model comparison } \\
\mathrm{p}<2.2 \times 10^{-16}\end{array}$} & \multicolumn{2}{|c|}{$\begin{array}{c}\text { post-meal }{ }^{\star} 5 \text { stars: } \mathrm{b}=0.45, \mathrm{t}=7.3 \\
\text { model comparison } \\
\mathrm{p}<2.2 \times 10^{-16}\end{array}$} \\
\hline $\begin{array}{l}\text { triple interaction } \\
\text { effect } \\
\text { tp*meal_cat*taste }\end{array}$ & \multicolumn{2}{|c|}{$\begin{array}{c}\text { post-meal }^{*} \text { plant-based }{ }^{*} 5 \text { stars: } \mathrm{b}=- \\
0.15, \mathrm{t}=-0.8\end{array}$} & \multicolumn{2}{|c|}{$\begin{array}{c}\text { post-meal }{ }^{*} \text { plant-based }{ }^{*} 5 \text { stars: } b= \\
0.18, t=1.4 \\
\text { model comparison } \\
\mathbf{p}=\mathbf{0 . 0 3 5}\end{array}$} \\
\hline \multicolumn{5}{|c|}{ vegetarian only $(n=3456)$} \\
\hline $\begin{array}{l}\text { interaction effect } \\
\text { tp*meal_cat }\end{array}$ & \multicolumn{2}{|c|}{$\begin{array}{c}\text { post-meal }{ }^{*} \text { plant-based: } \mathrm{b}=-0.03, \mathrm{t} \\
=-0.4\end{array}$} & \multicolumn{2}{|c|}{$\begin{array}{c}\text { post-meal }{ }^{*} \text { plant-based: } \mathrm{b}=-0.13, \mathrm{t} \\
=-2.9 \\
\text { model comparison } \\
\mathbf{p}=\mathbf{0 . 0 0 4}\end{array}$} \\
\hline $\begin{array}{l}\text { double interaction } \\
\text { effect } \\
\text { tp*taste }\end{array}$ & \multicolumn{2}{|c|}{$\begin{array}{c}\text { post-meal }{ }^{*} 5 \text { stars: } b=-0.74, t=-4.5 \\
\text { model comparison } \\
p<5.1 \times 10^{-15}\end{array}$} & \multicolumn{2}{|c|}{$\begin{array}{c}\text { post-meal }{ }^{*} 5 \text { stars: } \mathrm{b}=0.47, \mathrm{t}=3.9 \\
\text { model comparison } \\
\mathbf{p}<2.2 \times 10^{-16}\end{array}$} \\
\hline $\begin{array}{l}\text { triple interaction } \\
\text { effect } \\
\text { tp*meal_cat*taste }\end{array}$ & \multicolumn{2}{|c|}{$\begin{array}{c}\text { post-meal }{ }^{*} \text { plant-based }{ }^{*} 5 \text { stars: } b= \\
0.33, t=0.8\end{array}$} & \multicolumn{2}{|c|}{$\begin{array}{c}\text { post-meal }^{*} \text { plant-based }{ }^{*} 5 \text { stars: } b= \\
-0.72, t=-2.5 \\
\text { model comparison } \\
\mathbf{p}=\mathbf{0 . 0 1 2}\end{array}$} \\
\hline \multicolumn{5}{|c|}{ vegan only $(n=911)$} \\
\hline $\begin{array}{l}\text { interaction effect } \\
\text { tp*meal_cat }\end{array}$ & \multicolumn{2}{|c|}{$\begin{array}{c}\text { post-meal }{ }^{*} \text { plant-based: } \mathrm{b}=-0.96, \mathrm{t} \\
=-6.6\end{array}$} & \multicolumn{2}{|c|}{$\begin{array}{c}\text { post-meal }{ }^{*} \text { plant-based: } \mathrm{b}=0.54, \mathrm{t} \\
=4.5 \\
\text { model comparison } \\
\mathrm{p}<6.99 \times 10^{-6}\end{array}$} \\
\hline
\end{tabular}


medRxiv preprint doi: https://doi.org/10.1101/2021.10.24.21265240; this version posted October 26, 2021. The copyright holder for this preprint (which was not certified by peer review) is the author/funder, who has granted medRxiv a license to display the preprint in perpetuity.

It is made available under a CC-BY-NC-ND 4.0 International license .

\begin{tabular}{|c|c|c|}
\hline $\begin{array}{l}\text { double interaction } \\
\text { effect } \\
\text { tp*taste }\end{array}$ & $\begin{array}{c}\text { post-meal }{ }^{\star} 5 \text { stars: } \mathrm{b}=-1.44, \mathrm{t}=-4.5 \\
\text { model comparison } \\
\mathrm{p}<4.2 \times 10^{-13}\end{array}$ & $\begin{array}{c}\text { post-meal }{ }^{*} 5 \text { stars: } \mathrm{b}=0.34, \mathrm{t}=1.4 \\
\text { model comparison } \\
\mathbf{p}<2.2 \times 10^{-16}\end{array}$ \\
\hline $\begin{array}{l}\text { triple interaction } \\
\text { effect } \\
\text { tp*meal_cat*taste }\end{array}$ & $\begin{array}{c}\text { post-meal }{ }^{*} \text { plant-based }{ }^{*} 5 \text { stars: } \mathrm{b}=- \\
1.4, \mathrm{t}=-1.8 \\
\text { model comparison } \\
\mathrm{p}=0.077\end{array}$ & $\begin{array}{c}\text { post-meal }{ }^{*} \text { plant-based }{ }^{*} 5 \text { stars: } b= \\
0.06, t=0.11 \\
\text { model comparison } \\
\mathbf{p}=\mathbf{0 . 0 4 5}\end{array}$ \\
\hline
\end{tabular}

Significant effects between linear mixed models model comparisons are marked in bold. 